\title{
C.G. JUNG, J.J. HONEGGER, AND THE CASE OF EMIL SCHWYZER (THE 'SOLAR PHALLUS' MAN)
}

\author{
RONALD V. HUGGINS
}

PHANÊS ・ VOLUME $4 \cdot 2021 ・$ PP. 82-151

https://doi.org/10.32724/phanes.2021.Huggins 


\begin{abstract}
The case of Emil Schwyzer, a.k.a. the 'Solar-Phallus Man', was foundational in giving shape to Jung's early reflections on the concept of the collective unconscious. In 1906 Schwyzer identified a tail of light coming off the sun as a phallus, which Jung interpreted as a particularly important example of 'the fantasies or delusions of...patients...[being] paralleled in mythological material of which they knew nothing' (Bennet 1985:69). This was because it represented not only a single mythological symbol or idea that Schwyzer could not have known but an entire passage from an ancient document known as the Mithras Liturgy. According to Jung, Schwyzer's 'vision' also paralleled a rare theme in Medieval art. Jung's student J.J. Honegger gave a paper on the Schwyzer case at the March 1910 Second Psychoanalytic Congress in Nuremberg. In it he again discussed Schwyzer's description of the light tail on the sun but especially his concept of a Ptolemaic flat earth. Relying largely on archival material not previously discussed, the present article provides a history of the Schwyzer case along with a thoroughgoing evaluation of what Jung and Honegger made of it.
\end{abstract}

\title{
KEYWORDS
}

J.J. Honegger, Emil Schwyzer, 'Solar-Phallus Man', Mithras Liturgy, Collective unconscious, Inherited ideas, Hortus Conclusus. 

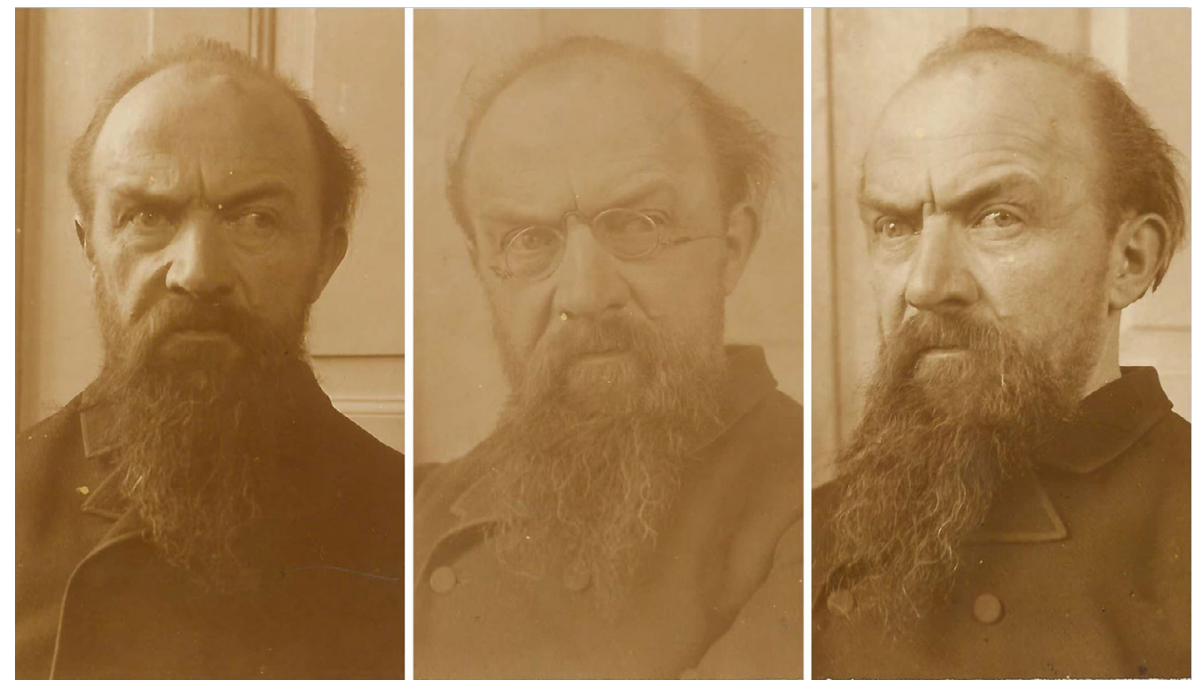

Emil Schwyzer (1862-1936) at Burghölzli on or before 3 May $1917 .{ }^{1}$

\footnotetext{
${ }^{1}$ Sent by Burghölzli Director Eugen Bleuler to Prof. Eduard Schwyzer on 3 May 1917 with an accompanying letter identifying the patient by name, date of birth, and the beginning of his institutionalization at Burghölzli ('Fotos der Familie Johann Salomon Schwyzer 1829-1912', in Archiv der Familie Schwyzer oder Schweizer, Stadtarchiv Zürich VII. 191).
} 


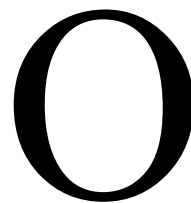
ne day in 1906 C.G. Jung, then in his mid-thirties, was going about his duties at the Burghölzli psychiatric clinic, when he came upon a patient named Emil Schwyzer who was acting strangely. Schwyzer was looking out the window at the sun and wagging his head back and forth. When he saw Jung, he excitedly took hold of him, led him over to the window, and said: ${ }^{2}$

Doctor! Now! Now you will see. Now look at it. Look up at the sun and see how it moves. See, you must move your head, too, like this, and then you will see the phallus of the sun, and you know, that's [the] origin of the wind. And you see how the sun moves as you move your head, from one side to the other! (Jung \& Freeman 1959:434).

At the time, Jung 'did not understand it at all', and dismissed it as Schwyzer's being 'just crazy' (Jung \& Freeman 1959:434, cf. Jung 1935:41 / CW 18:§85). But then in 1910, Jung came across a passage in Albrecht Dieterich's Mithrasliturgie that seemed to parallel very closely, even perhaps 'word for word', what Schwyzer had been describing that day four years earlier. ${ }^{3}$ Jung appears to have obtained the book and read it, or at least part of it, sometime between 10 July and 31 August $1910 .^{4}$

For Jung, the Schwyzer case would become important as evidence for the concept of inherited ideas, a foundational element in his concept of the collective unconscious. It seemed to represent an unusually straightforward example of cases where 'the fantasies or delusions of...patients were paralleled in mythological material of which they knew nothing' (Bennet 1985:69), parallels that might 'arise anywhere, at any time, without there being the slightest possibility of any...transmission' (Jung 1929:111/CW 8:§228). In his 1937 Terry Lectures at Yale University, Jung explained that: 'certain ideas exist almost everywhere and at all times and they can even

${ }^{2}$ For the year 1906, see Jung 1931:150-151/ CW 8:§318-319, 1934:50 / CW 9.I: $\$ 105$, 1956:158/CW 5: $\$ 223$.

${ }^{3}$ For the use of 'word for word', see Jung 1935:42/CW 18: $\S 85$, and 'almost word for word’ Jung 1929:111/CW 8:§228.

${ }^{4}$ At the bottom space of a letter from Freud dated 5 July 1910, Jung wrote upside down: 'A. Dieterich. Eine Mithrasliturgie. Teubner' (Freud \& Jung 1974:340, n. 8 [201F], Henceforth 'F/J'). Then, at the head of a 31 August 1910 letter to Freud, Jung quotes a passage from the last page of the Greek text of Dieterich's edition: 'Motto for

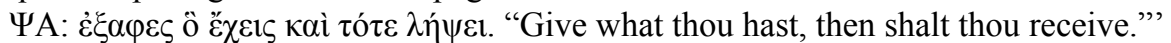
(Mystic injunction from a Magic Papyrus, Paris, the so-called Mithras Liturgy.)' (F/J 210J:350 = Dieterich 1910:21). 
spontaneously create themselves quite apart from migration and tradition' (Jung 1938b:4). The Schwyzer case was of particular importance to Jung because it represented, not just an idea or symbol, but an actual ancient text that manifested itself independent of any 'migration and tradition' in a patient's delusional fantasies and hallucinations.

Often, when relating the story, Jung would insist that Schwyzer could not have known about the parallel passage from Dieterich's Mithrasliturgie in 1906 because the book was not published until four years later (i.e., 1910). But this, as has often been noted, was not correct (Shamdasani 2012:51-53). The 1910 edition that Jung bought and read was the second edition, the first having appeared in 1903. Both editions contain the crucial passage, on the same page, and without variation (Dieterich 1910:6-7 and 1903:6-7). It was apparently only after Jung's last published account of the 1906 incident in 1959 that this discrepancy became known to Jung. More on this later.

Critics of Jung's interpretation of the Schwyzer incident have highlighted this mistake (e.g., Noll 1994:184; Eissler 1990:35, n.8). The standard response to them has been to stress that Schwyzer had been institutionalised already before 1903, and that therefore it was still highly unlikely that he had seen the Mithrasliturgie. ${ }^{5}$ Deirdre Bair elaborated on this defense by claiming that 'Jung checked his [i.e., Schwyzer's] previous hospitalizations and ascertained that there had been no patients' library in any of them' (Bair 2003:176 = 2007:252, followed by Lachman 2010:92; Lachman to the author, 4 Apr. 2014; and Hogenson 2004:42). Bair gives no source for this information, and no account I have seen includes it. It is in any case probably not true. Bair's assertion is categorical, and yet we know, for example, that Bethlem, where Schwyzer spent over a year, had lending libraries (plural) for patients, consisting of each ward having its own shelf of books and some arrangement for transferring them from one ward to another as they were called for. ${ }^{6}$ Eugen Bleuler, who was

\footnotetext{
${ }^{5}$ See Jung (1934:51, n. 5 / CW 9.I:§105); Bair 2003:188 = 2007:269-270 [German ed.], William McGuire's handwritten comment on Eissler 1990:35, n.8, also McGuire to Eissler, 7 May 1990:2 (William McGuire Papers, Bx 86, Fd 11, Manuscript Department, Library of Congress, Washington, DC).

${ }^{6}$ Albeit before 1903. See, Gale and Howard 2003:7. When asked about the use of the plural, Colin Gale, Director of the Bethlem Museum of the Mind, responded: 'That phrase "lending libraries" conjures up something rather grander than actually was the case at Bethlem in the late nineteenth century. The fullest report we have of the library comes from the Hospital magazine "Under the Dome" for 1898, from which we learn that 1,778 volumes were in circulation throughout the Hospital in that year. The reason for the plural "libraries" is that each ward would likely have had their own shelf or shelves of books in circulation, as well as access (via a member of Hospital staff
} 
the director of the Burghölzli clinic during the relevant years, seems to imply that in Schwyzer's time a similar situation was in place there as well. 'Even on the disturbed wards', Bleuler wrote, 'reading matter should be available' (Bleuler 1950:479=1911:386 [German ed.]). ${ }^{7}$ Eveline Isler of the Staatsarchiv of the Canton of Zürich said she considered it 'very likely' (äusserst wahrscheinlich) that the patient library at Burghölzli predates the beginning of the $20^{\text {th }}$ century because the archive catalog includes documents relating to collections of musical scores and theater pieces used there before 1900. Isler also shared the suggestion of a long-time employee at the archive that the clinic's chaplain (Anstaltspfarrer) had looked after the library in the early years (Eveline Isler to Sarah Löcker, 22 Apr 2014). In any case, reading was clearly part of the routine of daily life for patients in those years. In the source already quoted, Bleuler went on to say that patients 'bothered by boredom should be given the opportunity to banish it' $(1950: 479=1911: 387)$. He also suggested in his standard textbook on Psychiatry, that patients who were idle, 'are best off in bed; if they want to occupy themselves, there is no objection to reading, writing, and feminine handwork' (Bleuler 1924:221=1916:155 [German ed.]). There were times when the privilege of reading was withheld, as in the case of Sabina Spielrein, who was admitted to Burghölzli on 17 August 1904. Spielrein's patient record reveals that, due to her extreme sensitivity at one point soon after her arrival, strict bed rest was ordered, as well as 'No books, no conversation, no visitors' (Steffens \& Wharton 2001:19). On 29 September 1904, Jung reports that Spielrein 'has no attention span when she is reading by herself, but the doctor's mere personal presence can often enable her to concentrate for hours' (Steffens \& Wharton 2001:21-22). In short, the claim that Schwyzer could not have seen the earlier edition of Dieterich because he had been in Burghölzli since before 1903 seems far who had taken on the responsibility) to information about what titles were available to borrow, and could be brought from other wards for the purpose. So far as we know, there was no central room or rooms in which all the books were kept... It is difficult to find direct evidence of this for 1888-1889 [the period Schwyzer was there], since the Hospital magazine only extends back as far as 1892, but certainly the library gets a (brief) mention in the first edition of that magazine, not as something that has just been put in place, but as something that is an established part of Hospital life' (Colin Gale to the author, 24 Aug 2020).

${ }^{7}$ Something more centralised than Bethlem's arrangement might be suggested for Burghölzli by Bleuler's reference to a Schizophrenic imagining that 'the edition of Goethe's works in the hospital library is full of hints at him and has been falsified for his sake' (1950:133-34=1911:109). There are uncertainties connected with this example. Was Bleuler referring to an event which took place in Burghölzli or some other hospital? Also, the German is less specific. It does not explicitly refer to Goethe as being in 'the hospital library' but simply in the institution or sanatorium (Anstalt). 
from watertight.

And yet this way of approaching the problem, insisting that Schwyzer could not have seen the Mithrasliturgie by 1906, though initiated by Jung himself, does little to clarify the actual situation. On the contrary, as we shall see, the question whether Schwyzer knew the Mithrasliturgie or not is ultimately irrelevant because Jung had misinterpreted the meaning of the crucial passage in that text. It really does not describe what Jung imagined it did. In addition, there is the problem of Jung's describing what Schwyzer saw in 1906 as a 'vision' or 'hallucination' of a solar phallus, when it was actually not that, but rather a delusional interpretation of a common visual phenomenon regularly experienced by almost everyone, enhanced to some degree in Schwyzer's case by the fact that his left eye was paralysed.

We shall suggest that these and other inadequacies in Jung's diagnosis, were due in large part to his eagerness to interpret Schwyzer's case through the lens of his own newfound enthusiasm for the study of mythological symbols as the key to understanding and treating psychiatric patients. This seems to have caused Jung to focus entirely on Schwyzer's 1906 solar-phallus incident, to the exclusion of other relevant facts in the patient's history. The exception was Jung's misinterpretation of the passage from the Mithrasliturgie, which was less his own fault than that of the Greek lexical tools available to him at the time. Given the situation, it would have actually been surprising if Jung had been able to see beyond the limitations of the Greek lexicons and Dieterich's own German translation in order to arrive at a more accurate reading of the passage.

\section{SCHWYZER'S CHRONOLOGY}

In order to set the stage for our broader discussion, we need to begin by trying to establish the basic outlines of Schwyzer's chronology, a task that, so far, has not been credibly undertaken. In attempting this we are dependent on Schwyzer's medical histories from England and Switzerland, items in the Staatsarchiv of the Canton of Zürich and the Stadtarchiv of the city of Zürich (both marked with asterisks), the manuscript of J.J. Honegger's 30 March 1910 lecture at the Second Psychoanalytic Congress, and Jung's published statements regarding the Schwyzer case. Naturally, contemporaneous descriptions of events are more secure than those merely recollected. But in what follows we have used both. In some cases we have been able to correct the record. 


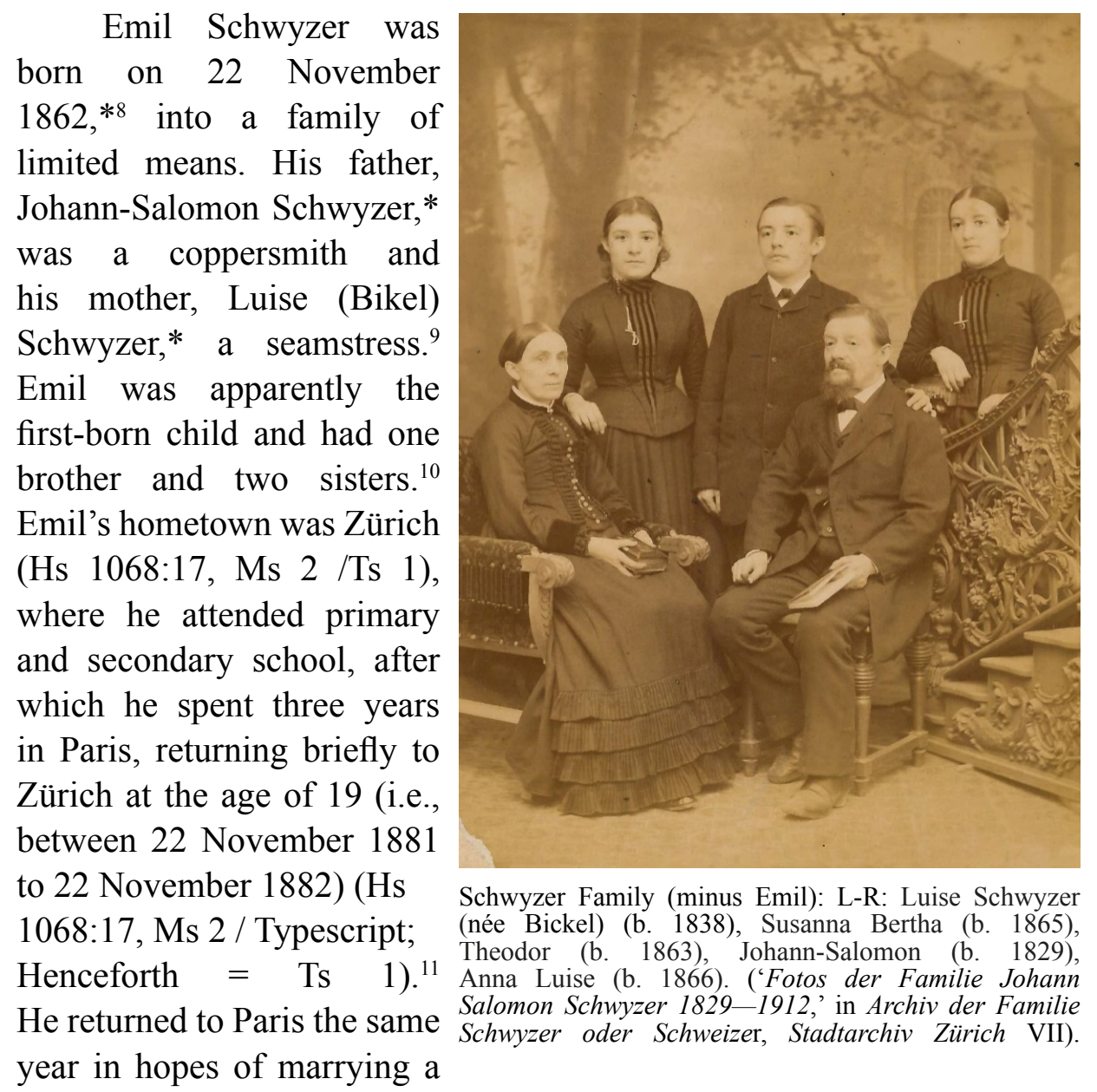

\footnotetext{
${ }^{8}$ The year is also given by the delusional Schwyzer to J.J. Honegger in 1910 as the 'Geburtstag des Herrn', the 'birthday of the Lord' in the paper Honegger presented on his case at the March 1910 Second Psychoanalytic Congress in Nuremberg: 'Über paranoide Wahnbildung' (Hs 1068:17, Ms 4/Ts 3; Honegger Papers in the C.A. Meier Papers, ETH Archive, Zürich). In the same paper, Honegger said Schwyzer's was 48 years old (Hs 1068:17, Ms 2/Ts 1). Actually he was 47.

9 The information on the father, mother and brothers from Krankengeschichte/ Patientenakten Z 100.7888 Emil Schwyzer (1862-1936) is in the Staatsarchiv of the Canton of Zürich (Verena Rothenbühler to the author, 8 Feb 2021), also 'Fotos der Familie Johann Salomon Schwyzer 1829-1912' in Archiv der Familie Schwyzer oder Schweizer, Stadtarchiv Zürich VII. 191 (Nicola Behrens to the author, 9 Feb 2021), and Hs 1068:18, intro. page prior to page 1.

${ }^{10}$ Hs 1068:18, intro page prior to page 1, says Schwyzer had two brothers. It may be, however, that he had only one, Theodor (b. 18 October 18, 1863).* Schwyzer's parents were married on 28 October $1861 *$ (Nicola Behrens to the author, 9 Feb and 11 Feb 2021).

${ }^{11}$ With the detail that he had actually spent 3 years in Paris and that he was 19 when he returned coming from Hs 1068:18,1, ETH Archive, Zürich.
} 
girl there. But she refused him so he went to England (Hs 1068:18,1), where we find him six years later in early 1888 living at 28 Finsbury Square \# 13, London, and working as a clerk at the International Bank. ${ }^{12}$

One day Emil found an envelope on his desk at the bank. Hoping it brought news of a promotion, he was shocked to discover instead that it was a notice of dismissal. He left work without collecting his pay, wandered around in a daze for 3 days (F/J 29J:57, 4 June 1907), ${ }^{13}$ and then took a revolver and put a bullet in his head (Hs 1068:18,2, F/J 29J:57, 4 June 1907). ${ }^{14}$ He was admitted to Guy's Hospital, London, on 12 February $1888 . .^{15}$

At the time Schwyzer was 25 years old. The heading of the summaryrecord from Guy's Hospital contains an error regarding Schwyzer's age at the time. At first glance it seems to read: 'Abstract of Report of Emile Schweitzer oct 19' (ibid). ${ }^{16}$ October 19 , however, makes no sense because the record itself, which covered only the period from 12 February to 14 April 1888, seems to have been sent along with the patient when he was transferred to Bethem on the latter date. But as Colin Gale, Director of the Bethlem Museum of the Mind, helpfully points out, 'It's not Oct. 19, it is aet. 19. Aet. is Latin for "age"-the record is simply of the patient's age upon admission' (Gale to the author, 28 Aug 2018).

Guy's hospital seems to have been under the impression that Schwyzer was 19. This mistake, however, was not repeated in the Bethlem records when Schwyzer arrived there. They put his age down correctly as 25 (Casebook Males 1888, \# 38:[1]). The error in Guy's record is interesting because Honegger also incorrectly reports that Schwyzer was 20 when he attempted suicide (Hs 1068:17, Ms 2/Ts 1). The English edition of the Freud/Jung letters too says he was 20 at the time (Freud \& Jung 1974:57 [29J] [4 June 1907]. Henceforth F/J). Both the German edition of the letters and the original letter itself, however, say he was 24 not 20,

\footnotetext{
12 'Abstract of Report on Emile Schweizer aet. 19', [1888] [1], from Guy's Hospital record which, along with its envelope, was pasted into Casebook Males 1888, \# 38:[4], Bethlem Art and History Collection Trust. His address comes from Casebook Males 1888, \# 38:[1], except for the \# 13, which may be delusional, which is reported in F/J 29J:57 (4 June 1907), and Hs 1068:18, 2.

${ }^{13}$ Schwyzer is not named in this letter, but it is undoubtedly his case that is being spoken of, as we shall see.

${ }^{14} \mathrm{Hs} 1068: 17$, Ms 2/Ts 1, mentions the suicide attempt but not the bullet to the head.

15 'Abstract of Report on Emile Schweizer', Guy's Hospital, [1].

16 Throughout the record the month is given first and then the day.
} 
which is closer to the truth (Freud \& Jung 1974a:63). ${ }^{17}$ It was perhaps this mistake in the English edition that led Deirdre Bair to give 1882, a date six years too early, as the time of the suicide attempt (Bair 2003:174= 2007:249), although on 12 February 1882 Schwyzer would have been 19 not $20 .{ }^{18}$ It seems unlikely however that she got her date from the mistake in the Guy's hospital abstract, because, although she was somehow aware that Schwyzer had been in two different hospitals in England, she only knew the name of the second, Bethlem. The first (Guy's) she refers to only as an 'unnamed London hospital' (2003:174, cf. 2007:249).

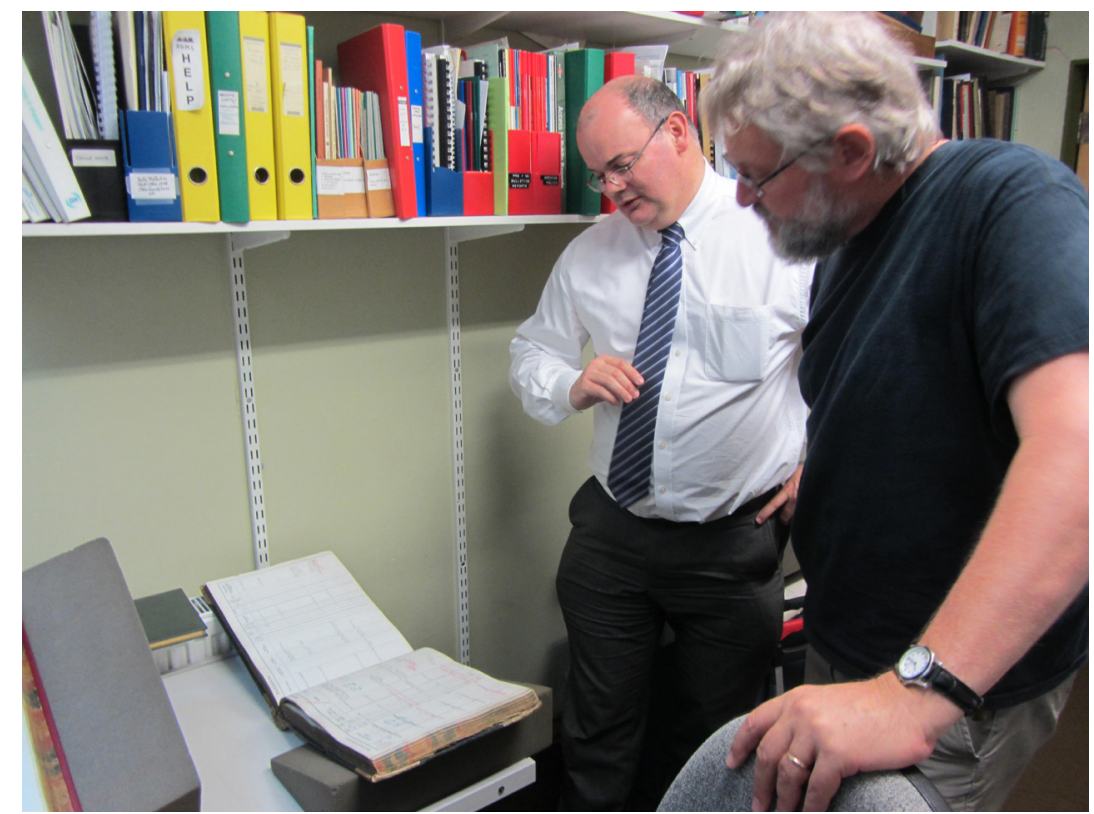

Colin Gale, Director of the Bethlem Museum of the Mind (left), explains the 11 July 1889 entry on Emil Schweitzer [sic] in the Bethlem Royal Hospital Register of Discharges and Deaths for 1885-1890 (Photo: Isaiah Johnson)

In any case, Schwyzer remained at Guy's hospital from 12 February until 14 April 1888, at which time he was transferred to Bethlem Royal Hospital, where he remained until 3 July 1889 (Colin

\footnotetext{
${ }^{17}$ For the original letter, see the Sigmund Freud Papers, Bx 33, Manuscript Division, Library of Congress, Washington, D.C. A copy was kindly provided to the author by Patrick Kerwin (10 Sept 2014). With the exception of the present reference, I do not give page numbers for the German edition of the Freud/Jung letters because they are double referenced in both editions by number and date.

${ }^{18}$ Bair was aware that it was Schwyzer's case being reported in F/J 29J:57-58 (4 June 1907) (Bair 2003:705-706, n. 17 \& 2007:993, n. 17).
} 
Gale to author, 2 July 2014). ${ }^{19}$ Honegger, then, was basically correct when he said that Schwyzer was hospitalised in England for about a year and a half (Hs 1068:17, Ms 2/Ts 1 and 1068:18,2). His source was probably the records from Münsterlingen, where Schwyzer was interned from 1897-1901, which noted that Schwyzer was 'already mentally ill in London in the $20 \mathrm{~s}$ and there for $11 / 2$ years in an institution' ${ }^{20}$

At the time of his admission to Bethlem, Schwyzer was described as a 'rather delicate looking man. Medium height, brown hair, pale face, Talks Swiss-German but understands very little English...The lines on his face are rather more marked on [the] $\mathrm{L}^{\text {[ef] }}$ side than on the right $\mathrm{R}^{\text {[ight] }}$ [,] especially when he smiles [,] but the two sides of his face are not naturally equally developed, his nose not being straight but inclined to the

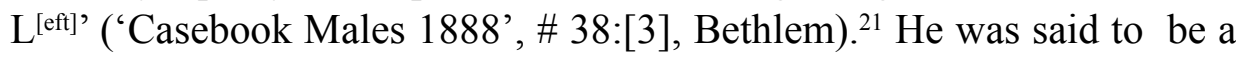
Protestant, a man of sober habits, with a 'fairly good' education, whose attempt at suicide had been prompted by 'overwork' (Casebook Males 1888 , \# 38:[1]). ${ }^{22}$

${ }^{19}$ Also, Casebook Males 1888, \# 38:[1 \& 4] has 3 July 1889 as the date of Schwyzer's release. B[ethlem] R[oyal] H[ospital] Register of Discharges and Deaths for 1885-1890:201), gives 11 July 1889. Colin Gale explains: 'in the nineteenth century, there was a sub-committee responsible for formally approving discharges from Bethlem that usually met weekly. Formal authority for discharges were given at these meetings, but the discharges themselves did not always, or even often, take place on the same day, in terms of when the patient actually departed from under the Hospitals' [sic] roof' Gale to the author, 25 July 2018.

20 'Nach dem ärztlichen Zeugnis war Referent schon in den 20er Jahren in London geisteskrank $u$. dort 1 1/2 Jahr in einer Anstalt' (Patientenakte Signatur Z 100.7888 Emil Schwyzer, in the Staatsarchiv of the Canton of Zürich. Verena Rothenbühler to the author, 2 \& 11 Feb 2021).

${ }^{21}$ Beginning in 1888, the year Schwyzer became resident there, Alfred Baker and Herbert Parker undertook taking pictures of Bethlem patients. These, along with others taken by hospital staff in the 1880s and 1890s, amounted to some 300 photographs (Gale \& Howard 2003:13). Unfortunately, Schwyzer does not appear to have been among those photographed (Colin Gale to the author, 17 July 2014).

${ }^{22}$ As to who might have overseen Schwyzer's case at Bethlem, Thomas Luck, the current Archivist there, explains: 'Neither I nor Colin [Gale] can convincingly make out the initials of the doctor signing it off [i.e., at the end of Casebook Males 1888, \# 38]. The Superintendent of the Hospital at the time is R Percy-Smith, and his deputy is Theo B Hyslop, but we believe it will be one of the clinical assistants who signs off Schwyzer's casenotes. As the handwriting changes regularly in the book [and in Schwyzer's own record], I would take this to mean that there is no one doctor treating him, and that he is probably being observed by a rotating cast of medical staff. In the year 1889 these are listed in the annual report of the Hospital as E Goodall, E Hobhouse, T Gordon Meikle, JP Boyd, J Cowper, HC Bristowe and GF Wickhamso we believe the initials are one of these, though we think they all had a role in his 
The greatest concern reflected in Schwyzer's records from Guy's hospital was his bouts of profound depression and his ongoing suicidal tendencies. He was often said to be restless ('Abstract of Report on Emile Schweizer', Guy's Hospital, [2-3]; Casebook Males 1888, \# 38:[1], 14[?] Apr 1888). He made a further suicide attempt on 25 March, trying to strangle himself with his head bandages, and then two days after that, he tried to persuade one of the attendants to kill him ('Abstract of Report on Emile Schweizer', Guy's Hospital, [2-3]). This may be the same incident described elsewhere, in which he asked the Sister of the Ward, a certain Helen Hermann, to help him obtain a pistol (Casebook Males 1888, \# $38:[1]) .{ }^{23}$ As we shall see later, Schwyzer was probably already delusional before shooting himself, at least as later reported. But he certainly was during his time at Guy's and Bethlem. A note entered into the Bethlem record from J.C. Steale [sic] of Guy's Hospital reports on how Schwyzer thought that 'one of the dressers intended to cut his head off and that the accidents received into the ward were caused by his faults' (Casebook Males 1888, \# 38:[1]). ${ }^{24}$ As we shall see, this last-mentioned delusion, the idea that he was responsible for harm done elsewhere, significantly foreshadows things to come. One of the most remarkable entries in the Guy's Abstract was made on 29 March 1888, where it is reported that Schwyzer 'Has a long story about a murder he has committed says he ought to die' ('Abstract of Report on Emile Schweizer', Guy's Hospital, [3]). Whether there was any substance to the story or not is anybody's guess. But it seems unlikely given how the overall sense of the evidence seems to suggest that Schwyzer was essentially a fragile and harmless soul.

Schwyzer's delusions continued at Bethlem as well. It is reported at an unspecified date in April 1888 that Schwyzer 'Sleeps badly-hears

treatment. If you were to force me to a guess I would take Gordon Meikle (it could conceivably be TGM)' (Luck to author, 29 Jan 2021). Indeed, Luck's seems the only possible guess, since the final initial does appear to be an M. But the initial(s) that come before really look nothing like a $\mathrm{T}$ and/or a $\mathrm{G}$.

23 A comment by Guy's Hospital's Edward Petronell Manby (misspelled as 'Manly') entered into the Bethlem Record. See Manby's obituary in The British Medical Journal 2 (28 Sept 1929):601; also, Thomas Luck to the author, 29 Jan 2021.

${ }^{24}$ Bethlem Archivist David Luck suggests that " "Steale" should actually be John Charles Steele, who by 1891 was Superintendent at Guy's Hospital', explaining that 'the doctor's certificates [two were required for entry at Bethlem] are transcribed into the casebooks from the original petitions sent to Bethlem. Because of this they are liable to misspellings or mistakes as the person writing in them tries to accurately copy the information in the original, including the signature' (Luck to the author, 29 Jan 2021, cf. also 2 Feb 2021). In this case both doctors' names were transcribed incorrectly. 
voices at night', and in the same entry, that he is 'Still suspicious \& thinks he is watched'. Then on 9 June of the same year, he is said to have 'Heard $\mathrm{D}[\mathrm{r}]$ Savage's voice last night "overhead." (ibid). ${ }^{25}$

There is no indication in the records of either Guy's or Bethlem hospitals that Schwyzer posed any danger to anyone else. The single instance in that direction took place on 12 June 1888 when Schwyzer 'Attacked an attendant + tried to get the Keys from him' (Casebook Males 1888, \# 38:[3]). Schwyzer did, however, make at least one further effort to harm himself on the night of 20 April 1888 by dashing his head against a door, which caused him to be consigned to the padded room for the night. We shall have more to say about this incident later.

Interestingly, the 'yes and no' forms that were filled out before a patient entered Bethlem did not list 'Delusions' and 'Depression' as separate items. Instead, they combined them in two forms: 'Delusions, Exaltation' and 'Delusions, Depression'. In Schwyzer's case the latter was affirmed with a 'yes' (ibid, 2). Next to the word 'Hallucinations' on the same page was written 'no'. 'Paranoia' or 'Paranoid', were not given as options. Neither the Guy's Hospital Abstract nor the Bethlem record make any reference to Schwyzer's experiencing visual hallucinations, only aural ones, the hearing of voices in the night, mentioned above. The significance of this will also become clear later.

After Schwyzer was released from Bethlem, he returned once more to Zürich, where he spent the next 8 years working as a commis, or clerk (Contra Hs 1068:17 Ms 2/Ts 1, which gives 9 years instead of 8). In March 1897, he had a second breakdown and was again institutionalised (Hs 1068:17, Ms 2/Ts 1), first at Mönchhof bei Kilchberg (Hs 1068:18,[8]), and then on 22 March 1897,* at Münsterlingen in Canton Thurgau, where he remained until he was transferred to Burghölzli on 7 October 1901.* (Hs 1068:18,5). He remained at Burghölzli until his death on 30 April 1936.*

Given the size, scope and influence of Deirdre Bair's biography of Jung it seems appropriate to pause in order to describe more fully her other departures from the chronology just presented. In addition to being off by several years on the date of Schwyzer's suicide attempt, she goes

25 Presumably Dr. George Savage, the Physician Superintendent (1878-1888). See Gale \& Howard 2003:9. Bethlem Archivist David Luck informs me that 'According to the Commissioners of Lunacy reports (a little more accessible than the minutes) Dr Savage left the Hospital after their visit in August 1888, so regardless of the medical staff's notes it is possible it was his voice on this point' (Luck to the author 2 Feb 2021). Luck's view, however, is that the staff recorded the incident because they assumed it was delusional. 
on to claim that Schwyzer was transferred to Bethlem in 1884 (actually 1888) where, she says, he remained until 1887 (actually 1889), at which time he was transferred to Mönchhof (actually ten years later, in 1897). Then on 22 March 1897 (correct), he was moved to Münsterlingen. From there, she says, he was transferred to Burghölzli on 27 October 1901 (actually 7 October 1901) (Bair 2003:174=2007:249). Finally she gives two different dates for Schwyzer's death, 1931 and 1937, neither of which is correct (actually 1936) (Bair 2003:174 = 2007:249 [German ed.] \& 2003:642 = 2007:912). Of all the dates Bair offers, 22 March 1897 as the time Schwyzer was moved to Münsterlingen is the only one that is correct. When confronted with Bair's chronology, Colin Gale of the Bethlem Museum of the Mind wrote: 'I note that one of your sources (mistakenly) suggests that Schweizer [sic] was hospitalised in Bethlem continuously from 1884 to 1887 . I don't know how this mistake arose, but I see that not all scholars have repeated it' (Colin Gale to the author, 11 July 2014).

\begin{tabular}{|c|c|c|}
\hline Event & Actual date \& age & Bair's date $\&$ age \\
\hline Birth & 22 Nov 1862 & 1862 \\
\hline Suicide Attempt & 12 Feb 1888 (25 yrs) & $1882(19$ or $20 \mathrm{yrs})$ \\
\hline Guy's Hospital & 12 Feb - 14 Apr 1888 (25 yrs) & $\begin{array}{l}1882-1884 \text { ( } 19 \text { or } 20 \mathrm{yrs}-21 \\
\text { or } 22 \mathrm{yrs})\end{array}$ \\
\hline Bethlem & $\begin{array}{l}14 \text { Apr } 1888-3 \text { Jul } 1889(25-26 \\
\text { yrs) }\end{array}$ & $\begin{array}{l}1884-1887 \text { ( } 21 \text { or } 22 \mathrm{yrs}-24 \\
\text { or } 25 \mathrm{yrs})\end{array}$ \\
\hline Mönchhof & Mar 1897 (34 yrs) & $\begin{array}{l}1887-1897 \text { ( } 24 \text { or } 25 \mathrm{yrs}-34 \\
\text { or } 35 \mathrm{yrs})\end{array}$ \\
\hline Münsterlingen & $\begin{array}{l}22 \text { Mar } 1897-7 \text { Oct } 1901 \text { (34-38 } \\
\text { yrs) }\end{array}$ & $\begin{array}{l}22 \text { Mar } 1897-27 \text { Oct } 1901 \\
(34-38 \text { yrs) }\end{array}$ \\
\hline Burghölzli & 7 Oct 1901 (38 yrs) & 27 Oct 1901 (38 yrs) \\
\hline Death & 30 Apr 1936 (73 yrs) & $\begin{array}{l}1931 \& 1937(68 \text { or } 69 \mathrm{yrs} \& \\
74 \text { or } 75 \mathrm{yrs})\end{array}$ \\
\hline
\end{tabular}

Bair seems to claim that Schwyzer was let out of Guy's hospital (which she does not name), only to be reinstitutionalized at Bethlem after 'several weeks', from which time he remained confined for the rest of his life (Bair 2003:174-175 = 2007:250). But none of this is 
accurate. Bair may have meant that there were 'several weeks' (instead of several years) between Schwyzer's release from Bethlem until his later institutionalisation in Zürich, or she may have been referring to the time between his leaving Guy's hospital and entering Bethlem. But as to the latter, there was no break of 'several weeks' between Guy's and Bethlem hospitals. Schwyzer was admitted to Guy's Hospital on 12 February and to Bethlem on 14 April. The last date in the Guy's record is 14 April $1888 .^{26}$ And when he was admitted to Bethlem that same day his suicide attempt was marked down as having occurred 8 weeks earlier ('Abstract of Report on Emile Schweizer', Guy's Hospital, [p. 3]; Casebook Males 1888, \# 38:[1], Bethlem).

Honegger more accurately reported that by 1910, Schwyzer's second confinement had been going on for the past 13 years (i.e., since 1897) (Hs 1068:17, Ms 2 /Ts 1). However, one thing that seems clear when reviewing the various sources is that Jung and Honegger did not have access to Schwyzer's medical records from England. ${ }^{27}$ As for Bair, it is possible that she tried to fill in the gaps in Schwyzer early chronology based on published statements Jung made after the details of the case were no longer fresh in his memory. Most notable in this regard is Jung's 1934 statement that Schwyzer 'was certified in his early twenties' (Jung 1934:52/CW 9.I: $\S 109$ ), or again his 1959 statement that by the time Schwyzer had his solar phallus 'vision' in 1906, he had been 'in the clinic or the ward twenty years' (Jung \& Freeman 1959:434). The latter statement may have been roughly true cumulatively, but it does not take into account the 8 years between Schwyzer's first and second confinements, i.e., from the time he was 26 to when he was 34 (i.e., from 3 July 1889 to the Spring of 1897). ${ }^{28}$

\section{JUNG'S 1907 DISCUSSION OF THE SCHWYZER CASE}

Jung joined the staff of Burghölzli on 10 December 1900. He was 25 years old. Less than a year later, on 7 October 1901,* Schwyzer was

\footnotetext{
${ }^{26}$ The last clearly legible date is 5 April (in the author's photographs of the document), Colin Gale feels confident that an inspection of the original makes it possible to identify the last date as the $14^{\text {th }}$ (Gale to author, 28 Aug 2018).

27 There are no records preserved from England in Krankengeschichte/Patientenakten Z 100.7888 Emil Schwyzer (1862-1936), nor for that matter from his time in Mönchhof in 1897 (Verena Rothenbühler to the author, 8 Feb 2021).

${ }^{28}$ Hs 1068:18, [8] incorrectly states that it was between his 22nd and his 34th (or possible 35 th) year. Is the 5 in $34 / 35$ written on top of the 4 in the manuscript, which seems more likely, or the 4 on top of the 5 ?
} 
admitted to Burghölzli. ${ }^{29} \mathrm{He}$ was 38 years old, with his $39^{\text {th }}$ birthday coming up the following month (22 November*). On the 31 December 1900 (the month Jung arrived) Burghölzli had 391 patients. Exactly one year later, on 31 December 1901 (two months after Schwyzer arrived), it had 360 (Brush 1905:653). With so large a number of patients it will be prudent for us to keep in mind in all that follows how little actual day to day contact Jung might have had with Schwyzer.

On 4 June 1907, Jung wrote to Freud describing the case histories of two patients, one of whom, who was suffering from Paranoia and Dementia Praecox, we know to be Schwyzer. He is not named and the description of the case does not include the well-known details Jung would later feature, but we can still be sure it is Schwyzer because the same strange series of unfortunate events, the same names, and even some of the same peculiar vocabulary, appear in both Jung's letter and Schwyzer's patient history (Hs 1068:18, 2).

The patient loses his job in London, wanders for three days, eating nothing. He is startled by a horse. A woman comes towards him whom he mistakenly takes for a 'cocotte' (the same word in both accounts). He imagines he sees Berty [Bertha Bosshardt? (Hs 1068:18, [6])] from Zürich with a man (in Schwyzer's patient history he initially thinks it is his brother). He notices his address is \#13, and then shoots himself in the head.

This letter reveals that Jung once knew that Schwyzer had left Zürich and traveled abroad, which contradicts the statement he made more than a quarter of a century later that Schwyzer had 'never travelled' (Jung 1934:52 / CW 9.I:§109). It also shows that Jung had heard about Schwyzer's head injury and suicide attempt, details he never mentions in his published accounts. Why did Jung pass over these details in later descriptions of the case? Is it possible that he forgot? Was the scar on Schwyzer's head, for example, still visible when Jung knew him? It probably was, although it was never very large. When the photographs of Schwyzer at the beginning of the article were taken (sometime before 3 May 1917) it is not noticeable at all (Fig. 1).

The record from Guy's Hospital described the wound at the time of his suicide attempt as 'the size of a small pea an inch in front of the left pinna [ear flap $\left.{ }^{30}\right]$... In front of this was a semicircular scorch. Its ant[erior] border was

\footnotetext{
${ }^{29}$ For the date of Jung's coming, see F/J, xv; Jung \& Jaffé 1965:111 = 2013:132. The 7 October 1901 date for Schwyzer's arrival is also noted in Schwyzer's patient history (Hs 1068:18, 5).

${ }^{30}$ According to the Oxford English Dictionary, 'The broad flap of skin-covered
} 


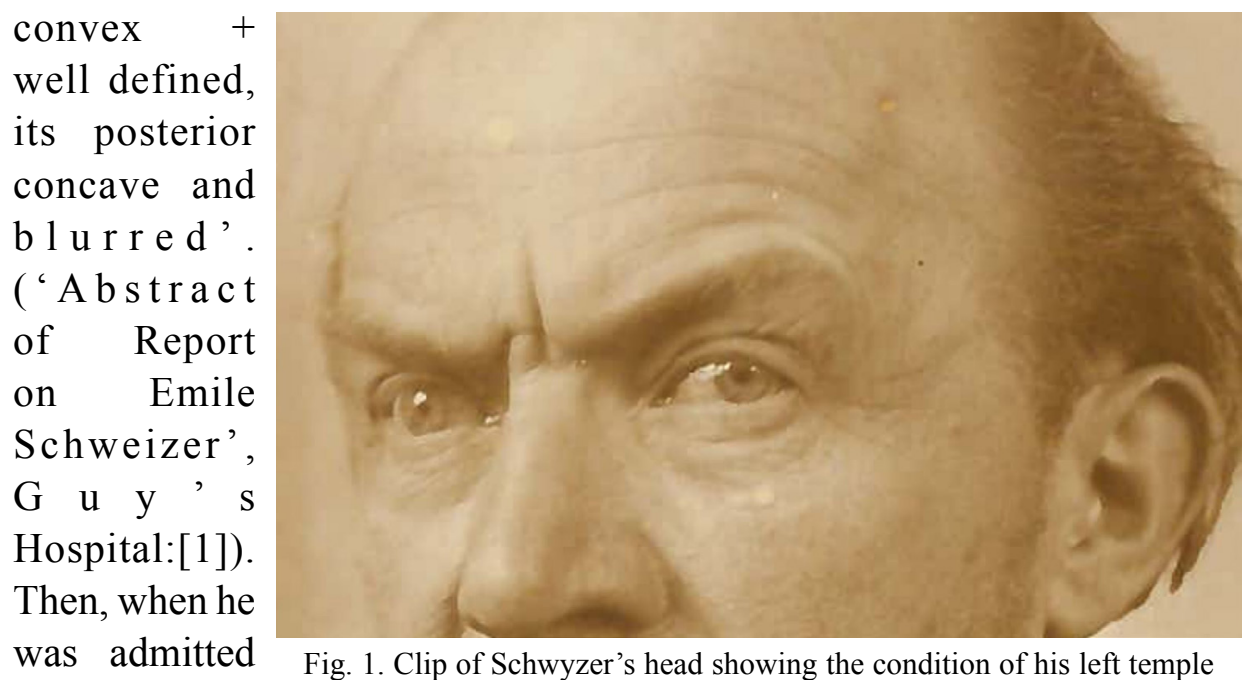
to Bethlem two (c. 1917 or before at Burghölzli).

months later, the wound appeared as 'a semicircular scar over $1[\mathrm{eft}]$-ear which is not yet quite healed' (Casebook Males 1888, \# 38:[3], Bethlem). Another description was given years later at the beginning of Schwyzer's second break down in the Spring of 1897. At that time, it was described simply as a scar from the gunshot wound in the left-temple area (Schussnarbe in der linken Schläfengegend). (Hs 1068:18, [8]). Very likely, then, the scar was visible when Jung knew Schwyzer, though perhaps not very prominent. But again, how often would Jung have actually encountered Schwyzer, and how closely would he have considered him when he did? And why should Jung pay much attention to Schwyzer? He seems to have been very repetitive in his delusional stories, but at the same time something of a model patient. Honegger described him as a diligent and capable worker in the hospital kitchen/scullery, a post he apparently held for a number of years. ${ }^{31}$ (Hs 1068:17 Ms 2 /Ts 1-2). In an environment where the squeaky wheel gets the grease, a patient like Schwyzer would have been easy to ignore.

Although Schwyzer's patient history did record that he had shot himself in the head, Honegger does not mention it in the manuscript of the 30 March 1910 paper he presented on Schwyzer in Nuremberg. ${ }^{32}$ There he only says that there had been a suicide attempt without going into details. cartilage which forms the external ear in humans and other mammals'.

${ }^{31}$ Schwyzer seems to have been engaged in his duties at the time of the 8 May 1902 eruption of Mount Pelée and the 28 December 1908 Messina earthquake (Hs 1068:17 Ms 11/Ts 9).

32 In 1976, C. A. Meier informed William McGuire that the Honegger's Papers, which Meier had in his possession, included his 1910 Nuremberg Paper. (McGuire to K.R. Eissler, 1 Mar 1976:2). The reference can only be to Hs 1068:17. 
(Cf. Hs 1068:17, Ms 2/Ts 1 and Hs 1068:18, 2). So if Honegger followed his manuscript closely, and Jung was in the audience, the latter would not have been specifically reminded about his own 1907 mention of the gunshot wound to the head. As we shall see, the reason the question is important is that the gunshot wound has more direct relevance for grasping the nature of Schwyzer's so-called solar phallus 'vision' than the question whether he was familiar with Dieterich's Mithrasliturgie or not.

\section{JUNG, J.J. HONEGGER, AND THE PASSION FOR MYTHOLOGICAL STUDIES}

Whatever Jung's interest in the Schwyzer case might have been in 1907, in 1910 it was given an entirely new focus that exclusively featured the 1906 incident of Schwyzer's seeing a phallus on the sun to the exclusion of everything else in his case history. In the few cases where Jung did appeal to other details from the case's history in the published accounts he tended to misremembered them. This new and narrower focus was the natural result of Jung's new-found fascination with the symbols of mythology. We are helped to see this by the chronology, this time Jung's and Honegger's.

Honegger never served, as one author put it, as 'one of his [Jung's] psychiatrists at the Burghölzli' (Noll 1997:102). As Shamdasani notes, Honegger 'was never a member of the permanent staff' (2003:215, n. 75). When he and Jung began their collaboration, Honegger had just recently completed medical school in Zürich (Spring, 1909), had not yet submitted his dissertation, and was not at the time (or ever) an employee of Burghölzli (Walser 1974:245). But he would spend two months there as a volunteer, and the timing of that would be significant.

Jung had submitted his resignation to Burghölzli on 7 March 1909 (Möller, Scharfetter, Hell 2002:449.), but he did not begin moving his family out of his rooms there and into his new house in Küsnacht until 25 May 1909 (F/J 142J:224 [2 June 1909]: 'last Tuesday'). On 21 June, he wrote to Freud for the first time about a 'very intelligent and subtleminded' studiosus named J.J. Honegger who 'wants to take up psychiatry, [and] once consulted me because of a loss of reality-sense lasting a few days' (F/J 148J:237).

Soon after Freud and Jung had returned from the Clark Conference in America at the end of September 1909, Jung began to speak of a newfound passion: the study of the symbolism of ancient mythology. ${ }^{33}$

${ }^{33}$ Jung credited a famous dream he had on his way back from America of a house 
One of the first hints of it comes in a 14 October 1909 letter to Freud, where Jung refers to 'reading with pleasure', Thomas Inman's Ancient Pagan and Modern Christian Symbolism Exposed and Explained (1874). (F/J 157J:251). On 8 November he writes telling Freud that he has been 'immersed every evening in the history of symbols, i.e., in mythology and archaeology...Rich lodes open up for the phylogenetic basis of the theory of neurosis' (F/J 159J:258). Jung uses the term phylogenic to refer to inherited ideas. In the same letter he mentions he was reading Friedrich Creuzer's four-volume Symbolik und Mythologie der Alten Völker (191021), ${ }^{34}$ and a 'capital book', by Richard Payne Knight, A Discourse on the Worship of Priapus, and Its Connection with the Mystic Theology of the Ancients (1865 [1786]). On 15 November he told Freud, 'I spend much of my time with young Honegger...Hardly a day goes by without an exchange of ideas...For me there is no longer any doubt what the oldest and most natural myths are trying to say. They speak quite "naturally" of the nuclear complex of neurosis' (F/J 162J:262-263 [15 Nov 1909]). From the larger context of the letter it appears that the subject of his and Honegger's daily discussions included phallic symbolism, which is also a prominent theme of the letter.

On Christmas day 1909, Jung reported that 'Honegger...is now working with me with great understanding, and I shall entrust to him everything I know so that something good can come of it. It has become quite clear to me that we shall not solve the ultimate secrets of neurosis and psychosis without mythology and the history of civilization' ( $\mathrm{F} / \mathrm{J}$ 170J:279). Before Jung wrote his next letter to Freud, Honegger had become a 'voluntary worker' at Burghölzli, which he was from 7 January-12 March 1910. ${ }^{35} \mathrm{He}$ spent the two months focusing almost exclusively on the Emil Schwyzer case, spending an hour or two each day with the patient (according to Hs 1068:17, Ms 1/Ts 1).

From that time forward until the 30 March Nuremberg meeting,

in which each story reflected a different age of humanity (Jung 2012:23-24). Kenny argues that the dream itself was inspired by a paper by Franz Boas given at the Clark Conference (Kenny 2012:181).

${ }^{34}$ Later Jung would recall his enthusiasm in reading Creuzer: 'I went through the three or four volumes at top speed, reading like mad, in fact' (Jung 2012:24).

35 It is Jung who describes Honegger's position at Burghölzli in F/J 186J: 308 (17 April 1910): 'In Burghölzli my policies are regarded with displeasure...Honegger, who was there as a voluntary worker, came down so heavily on my side that he immediately lost contact with the clinic'. Also Hs 1068:17, Ms 1/Ts 1 p. 1: 'Volontär.' Dates come from Shamdasani (2003:215), citing the 'Index of directors, secondary, assistant and voluntary doctors at the Burghölzli since 1870', Burghölzli archives. 
things seem to have become increasingly busy for Jung and we hear less in his published letters about leisurely evenings discussing mythology with Honegger. At the beginning of the New Year, Carl and Emma took a brief vacation at Unterwasser (F/J 172J:284), after which Jung was taken up by a series of lectures delivered every Wednesday from 12 January-16 February on the announced subject of mental disturbances in children, but featuring what he had been learning about symbolism (F/J 175J [30 Jan 1910]: 288-289, n. 1). At the same time, he was putting together the July 1910 issue of the Jahrbuch für psychoanalytische und psychopathologische Forschungen. It is difficult to say to what extent Honegger was involved in the lectures or Jahrbuch prior to the 30 March meeting.

On January 30, Jung confided to Freud that he doubted whether Honegger would have the research he was working on ready for inclusion in that issue of the Jahrbuch. On this he turned out to be correct. On 2 March Jung informed Freud that he had 'asked Honegger for a lecture on D[ementia].p [raecox]' for the Nuremberg meeting, while at the same time saying he was about to begin work on his own paper for the meeting $(\mathrm{F} / \mathrm{J}$ 181J:299). On 8 March Jung left for Chicago where he spent most of the rest of the month while Honegger took over his patients and helped Emma with the final preparations for the meeting (Emma Jung to Freud, F/J: 301, 303 [8 \& 16 March 1910]). ${ }^{36}$ All the letters and telegrams sent home by Jung during this trip made mention of Honegger, but nothing is said about the latter's upcoming paper. Jung does make mention on the ship home that he is working on his own paper for the Congress. ${ }^{37}$ Upon reaching Europe, Jung went directly from the boat to the Nuremberg meeting (Thomas Fischer to the author, $2 \mathrm{Feb} 2021$ ). It is quite possible therefore that the first and even perhaps the only full encounter Jung ever had with Honegger's paper prior to the publication of Wandlungen und Symbole der Libido was when he heard it delivered on 30 March at the Nuremberg meeting. In any case, the day after Honegger gave his paper Jung enthusiastically reported to Emma that Honegger's paper had gone well (Honegger grossartig abgeschnitten). (Comment made in a 31 March 1910 letter sent from the meeting on Nuremberg's Grand Hotel stationary. Thanks to Thomas Fischer for providing me with this reference, Fischer to the author, 16 Dec. 2020).

\footnotetext{
${ }^{36}$ Thomas Fischer informs me that 'Honegger is mentioned in every letter by Jung sent from his impromptu trip to the USA (as H[onegger] is staying in the Jung-House, looking after Jung's practice and patients left behind)' (Fischer to the author, 16 Dec. 2020).

${ }^{37}$ According to Thomas Fischer, who kindly reviewed the unpublished letters in the Jung Family Archive in order to provide the author with this information (Fischer to the author, 2 Feb 2021).
} 
We may ask why, given the great number of patients at Burghölzli, Honegger chose Schwyzer as the focus of his attention for special study? There could have been any number of reasons, but what he and Jung had been so earnestly studying together during the previous two or three months would have surely played into it somehow. A good deal of what Jung had been reading dealt with phallic symbolism, not infrequently presented with solar associations. We see this in his exchanges with Freud at that time. On 15 November 1909, for example, Jung had said that the 'dying and resurgent god (Orphic mysteries, Thammuz, Osiris, [Dionysus], Adonis, etc.) is everywhere phallic' (F/J 162J:263), this following up on an 11 November letter in which Freud told Jung that 'Oedipus is thought to have originally been a phallic demon' claiming that his name 'means simply erection' ${ }^{38}$ In the same letter Freud also mentions that, after hearing Jung praise Knight's A Discourse on the Worship of Priapus (mentioned above), he too had also ordered himself a copy (F/J 160F:260).

The three works Jung mentions reading at the time, Creuzer, Knight, and Inman, shared two things in common. First, they were all something beyond outdated by the time Jung read them, something indeed more like obsolete. Second (which flowed from the first), they all shared the naïve assumption, a common one at that early stage of research, that all religions and religious symbolism ultimately derived from a single source, although there was a great deal of difference of opinion as to what that source might be. This assumption dovetailed well Jung's developing idea of a single origin of ideas rooted not in a single historical source whence they worked their way outward finding a multiplicity of local expressions throughout the world, but in a shared inherited source in the human psyche itself whence they might emerge independently anywhere, at any time.

The problem is that sweeping claims of the sort made in these early works as to the common origins of religions, the meanings of their iconography, monuments, myths, and symbols, ran way out ahead of the evidence that would have been needed to make them credibly. The necessary languages and texts were not yet adequately known. ${ }^{39}$ Knight's book and the editions of Creuzer in Jung's library had been published prior to both Jean-François Champollion's 1822 announcement that he had succeeded in deciphering hieroglyphics using the trilingual Rosetta

\footnotetext{
${ }^{38}$ A surmise based on the fact that Oedipus means 'the swollen footed' (oĩ $\delta$ o $\varsigma=$ swelling \& $\pi$ oú $\varsigma$ foot). See also F/J 163F:266 (21 Nov 1909).

${ }^{39}$ This level of outdatedness did not apply to Thomas Wright's 'Essay on the Worship of the Generative Powers during the Middle Ages of Western Europe', which was added to, and amounted to more than half of the 1865 edition of Knight's work (originally, 1786). Jung owned the 1865 edition.
} 
Stone (Hierogliphic, Demotic, Greek), ${ }^{40}$ and Sir Henry Rawlinson's 1835 copying of the first characters from the trilingual Behistun Inscription in Iran (Old Persian, Elamite, Babylonian), which would ultimately provide the key to cracking cuneiform, the script used in Nineveh and Babylon (Rawlinson 1898:58).

In addition, despite the fact that a great enthusiasm for India had emerged in Germany in the latter part of the eighteenth century, especially after 1790, very few classic Hindu or Buddhist texts had yet become available in European Languages, and hardly any Europeans could read Sanskrit. The first to learn it was the Englishman Charles Wilkin who also produced the first translation of a classical Sanskrit text in a European language: The Bhăgvăt-gēētā, or, Dialogues of Krěěshnă and Arjǒŏn (1785). The first German said to have learned Sanskrit was Friedrich Schlegel, who began his studies of the language in 1803 (Feldman \& Richardson 1972, 352). Access to actual classical Indian texts of any sort remained patchy for some time after, as we see in Schopenhauer's recollection that ' $\mathrm{Up}$ till $1818 \ldots$ there were to be found in Europe only a very few accounts of Buddhism, and those extremely incomplete and inadequate, confined almost entirely to a few essays' (Schopenhauer 1969:2,169 = 1912-1913:2,208) ${ }^{41}$ This continued to be the case well into the $19^{\text {th }}$ century. The first complete edition of the Dhammapada in a Western language (Latin), for example, did not appear until 1855 (Fausbøll, 1855). By the time Jung became interested in mythology the situation had greatly changed, not least thanks to the 50 volume Sacred Books of the East series edited by F. Max Müller between 1879 and 1910. Jung would eventually own a complete set. But that came later.

By the end of the $19^{\text {th }}$ century single-source theories of the origin of religion and mythology had come under serious scrutiny, as Folklorist Andrew Lang wrote in a work published in 1897: 'these resolutions of myths into this or that original source-solar, nocturnal, vegetable, or what not-are often very perilous. A myth so extremely composite as that of Osiris must be a stream flowing from many springs, and, as in

\footnotetext{
${ }^{40}$ Revealing the same to the public at large in the same year in his Lettre à M. Dacier relative à l'alphabet des hiéroglyphes phonétiques. Champollion published his ample though still quite provisional Précis du système Hiéroglyhique des Anciens Égyptiens in 1824.

${ }^{41}$ Other examples of texts becoming available include, e.g., Méridas Poullé's French translation of a Tamil version of the Bhägavata Purāna (1788), Friedrich Maier's German (1802) and J.P. Paurraud's French's (1787) translations of the Bhagavad Gita, and William Carey \& Joshua Marshman's 3 volume English edition of the Ramayana (1806-1810).
} 
the case of certain rivers, it is difficult or impossible to say which is the real fountain-head (Lang 1897:xxii). Given the proliferation of fanciful interpretations early on in the study of myth and comparative religion, characterised as they often were by an over-readiness to equate figures from different religions and mythologies buttressed by erroneous etymologies and misinterpretations of iconographic details, the progress of the $19^{\text {th }}$ century involved not only learning new things, but unlearning old ones, and toppling older erroneous certainties. ${ }^{42}$ Lang summed up the situation at the end of the century well when he wrote: 'The history of mythology is the history of rash, premature, and exclusive theories. We are only beginning to learn caution'. (Lang 1897:xxiii). But all this happened after the books Jung started his myth studies with were written. It is to those we shall now turn our attention.

The German Romanticist Creuzer, steeped as he was in NeoPlatonic thought, would have naturally appealed to Jung, especially in his idea that the symbol was the foundational element upon which both myth and religion are built. According to Creuzer the symbol emerges from the human yearning to give birth to the infinite in the realm of the finite, i.e., to bring the realities from the realm of the ideas (the Forms), into this world of shadows. The symbol embodies the ambiguity and contradiction of the fruit of the attempt (Creuzer 1810:66-69, $\S 29-30) .{ }^{43}$ For Jung the

\footnotetext{
42 Examples abound, including the claim by Alexander Hislop, one of Inman's trusted sources, that 'Cannibal = Kahna-Bal, priest of Baal' (1871:325). Or again, Jacob Bryant's that the name of the Egyptian sun God Amon was derived from the name of Ham the son of Noah (1714:5), or that the name of Christ and the Hindu deity Krishna are etymologically related (see Huggins 2019), or that they are both sun gods based on claims such as Charles Vallancey's 'that Crishna in Irish means the Sun' (Jones 1806:262), that 'Krishen [Krishna]...and the nine Gopia...are clearly the Apollo and Muses of the Greeks', and that 'Hesus [sounds like Jesus!] was an appellative of the Sun' (Vallancey, 1786:537 \& 1782:38), or that Abraham was Saturn and Issac was Zeus' (Fourmont 1735:1.96), or Kaempfer's claim after seeing a statue of the Buddha in Siam, that 'The Saint being represented with curled Hairs, like a Negro, there is room to conclude, that he was no native of India, but was born under the hot Climate of Africa' (1727:38, Bk. 1:2, cf. Moor 1810:231-232; Hislop 1871:57). With so many errors and fancies in these older works it would have been difficult for Jung to avoid repeating at least some of them, as he did, for example, when he embraced Friedrich Nork's misreading of the $2^{\text {nd }} / 3^{\text {rd }}$ century Christian writer Tertullian which insinuated a link between the name of the goddess Athena (Pallas) and the word phallus (Nork 1843:229 $=$ Jung 1912a:212, Jung 1916:246-247).

${ }^{43}$ Creuzer 1810:108, § 40: 'Im Symbol nimmt ein allgemeiner Begriff das irdische Gewand an, und tritt als Bild bedeutsam vor das Auge unseres Geistes. Im Mythos äussert die erfüllte Seele ihr Ahnen oder Wissen in einem lebendigen Wort'. For Creuzer, as Burton Feldman has noted, 'the symbol keeps the infinite and finite, the spiritual and transient, in indivisible unity. The Creuzerian symbol is the thing
} 
realm of ideas could be transitioned over into the notion of the realm of the collective unconscious. When Jung read Creuzer, he would have found some discussion of phallic themes, but not in the way Richard Noll suggested when he wrote that "Jung never admitted (or had forgotten) that the mythological motif of a "solar phallus" (Sonnenphallus) was discussed by Creuzer in the third volume of his widely read mythological works' (1999:55). Noll refers to Creuzer's 1841 third edition, not the editions Jung actually owned, namely the first editions of volumes 1,2 , and 4 (1810, 1811 , and 1812) and the second edition of volume 3 (1821). ${ }^{44}$ The section Noll mentioned referring to a sonnenphallus made its first appearance in the much-expanded $18202^{\text {nd }}$ edition of volume 2 (670), which then migrated into the third volume of the third edition of 1841 (335), which is where Noll encountered it (see Noll 1999:81).

For his part, Knight identified the worship of masculine and feminine, the active and passive agents of generation, as the root of all religions. For him, the male organ representing the 'generative powers of God', and the female the 'generative powers of nature or matter' (1865:28). From his perspective the main task of the interpreter of religious and mythological symbols ultimately came down to trying to identify which symbols represented the male generative powers and which the female.

Inman, finally, drank deep from Knight, but also from such dubious sources as Geoffrey Higgins's ponderous Anacalypsis: An Attempt to Draw Aside the Veil of Saitic Isis; Or, An Inquiry into the Origin of Languages, Nations, and Religions (1836). Higgins was a Freemason who wrote his massive idiosyncratic work with an eye toward proving that Freemasonry was the original religion from which all others sprang forth. ${ }^{45}$

symbolized, where myth now only represents it' (Feldman \& Richardson 1972:388899).

44 Thanks to Thomas Fischer for providing me with this information regarding the editions of Creuzer in Jung's library.

${ }^{45}$ We see this in statements like: 'the [ancient Egyptian] mysteries were not the origin of Masonry; they were Masonry itself' (Higgins 1836, 1:719), 'I have no doubt that the Cabalistic oeconomy was similar to that of a lodge of Freemasons' (1:816), and 'Every part of Christianity refers back to Abraham, and it is all Freemasonry' (1:790). Higgins also gives a nod to the idea of Freemasonry's flowing in at least some sense from India: 'Masons were the builders of Solomon's temple, and they procured the wood Almug from India, whence they and their art came' (1:719). 
Of the three books Jung named, Inman's is most relevant to our discussion here. This is because of its singular and unrelenting search for examples of phallic symbols across all religions. For Inman, anything that was generally long and straight counted for a phallic symbol, and anything vaguely almond shaped, a vulva. ${ }^{46}$ According to Inman, symbols of the male, included 'towers or spires... and minarets... Whatever was upright, and longer than broad...A sword, spear...dart, battering ram, spade, ship's prow, anything indeed intended to pierce into something else' (1974:xxii-xxiii), 'a tall straight tree, especially the palm and the fir or pine...a tall upright stone... a cone, a pyramid, a thumb or finger

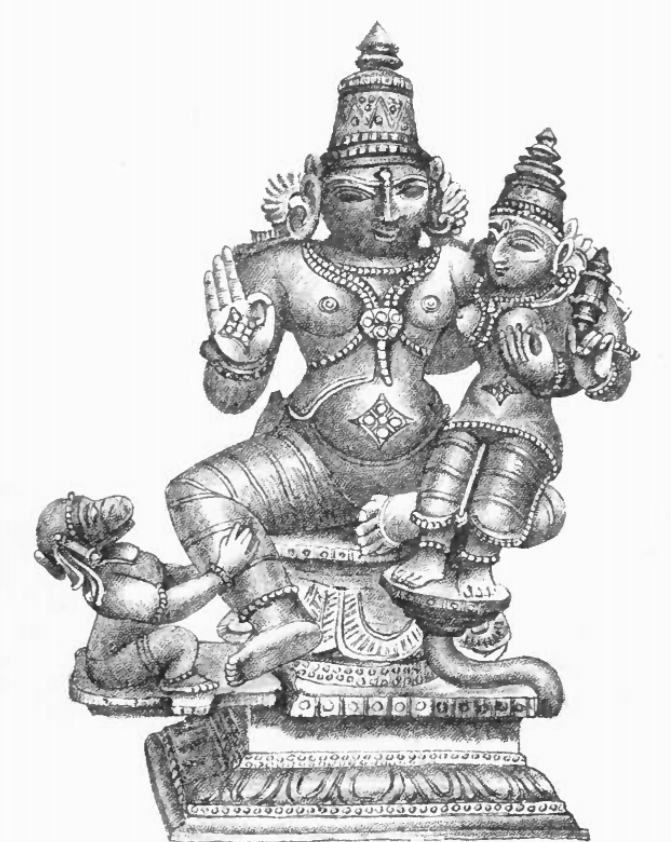

Fig. 2. Bronze of Rama, Sita and Hanuman (see footnote 46). pointed straight [the "phallic hand" (ibid:127)], a mast, a rod, a trident, a narrow bottle or amphora, a bow, an arrow, a lance, a horse, a bull, a lion,

\footnotetext{
${ }^{46}$ We may think of Inman's interpretation of the familiar vitarka-mudrā, a hand gesture signifying argumentation or discourse common to the art of Buddhism and also occasionally encountered in Hindu iconography as well (see, for example, Shiva as Dakshinamurthi). Because the gesture involved the tips of the thumb and forefinger touching one another and forming something like an almond shape Inman thought it must be 'the symbol of the yoni' (Inman 1875:18, Pl. XIV, cf., Vogel 1998:95). This misidentification is only the beginning of Inman's problems relating to this particular bronze (Fig. 2). He thinks the figures represent 'Parvati, the Hindoo virgin, and child', which he identifies as 'perhaps Crishna' (1875:18). But the sons of Shiva and Parvati are Ganesha and Karttikeya, not Krishna. The mother of Krishna is Devaki. The figures Inman identifies as mother and child clearly represent, not a virgin and child, but a male god and his female consort. The smaller figure has breasts, one of which the larger figure is fondling. The actual item was part of the Joseph Mayer Collection at the Free Museum of Liverpool (now the World Museum). The old catalogue identifies the larger figure as the god Vishnu, the smaller as the goddess Lakshmi, and the monkey to the right of Vishnu as the god Hanuman (Gatty 1882:87). The present writer's view is that the catalogue's identification is incorrect also, and that the male and female figures are Rama and Sita not Vishnu and Lakshmi. For a similar example without Hanuman but with vitarka-mudrā see the following Rama and Sita figurine from London's Victoria and Albert Museum: http://collections.vam.ac.uk/item/O480164/rama-and-sitafigures/.
} 
and many other animals conspicuous for masculine power', 'the sun, light, fire, a torch, the phallus or linga, an erect serpent' (ibid:115) or a non-erect serpent, 'a spear head, a hare, a tiara, a cock, and a tortoise'(ibid:99). The last mentioned was included in the list, Inman says, because its head and neck resembles a penis.

Horns count for phalluses too on the alleged grounds that 'in ancient symbolism, a part of a symbol stands for the whole' (ibid:124125). And, as we saw, bulls, along with other 'animals c on s p i c u o u s for masculine power' have horns (ibid:115). Pillars of

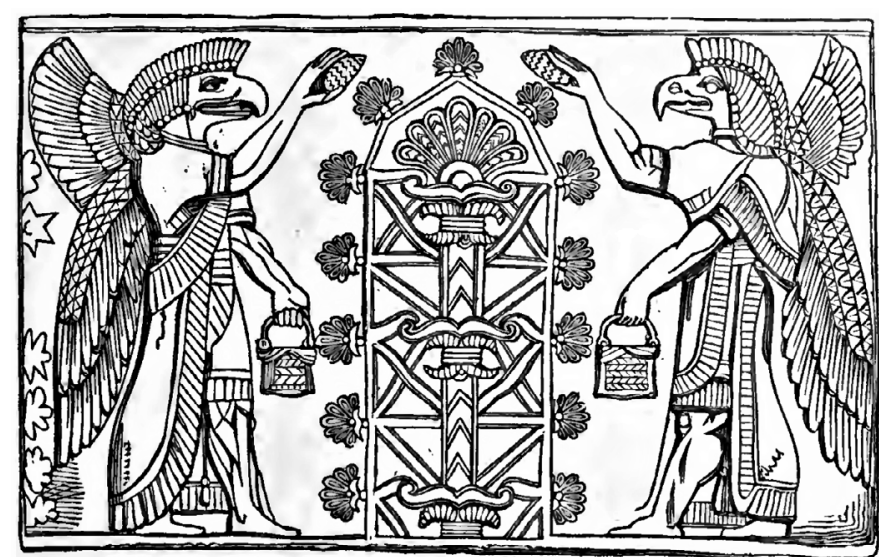

Fig. 3. Assyrian 'sacred tree,' in a panel from the Northwest Palace of Ashurnasirpal II at Nimrud (now in the Metropolitan Museum in New York) from Thomas Inman's Ancient Pagan and Modern Christian Symbolism (Fig. 176 / p. 126).

all sorts counted for phalli, even including the British Museum's three famous Assyrian obelisks (Inman 1875:99) ${ }^{47}$

A typical example of the kind of overreach one often found in the earlier period is Inman's phallic/vulvic take on the mysterious Assyrian 'sacred tree', in the panel from Northwest Palace of Ashurnasirpal II at Nimrud now in the Metropolitan Museum in New York (Fig. 3). In the picture two eagle-headed figures stand on either side of the tree with baskets and what look like pine cones (Fig. 2) (Inman 1875:31, fig. 18). ${ }^{48}$ Even now, however, the meaning of the image remains a mystery, since

${ }^{47}$ Presumably the Black Obelisk of Shalmaneser III (BM ANE 118885), the White obelisk of Assurnasirpal I(?) (ANE 118807), and the fragmentary 'Rassam' obelisk of Ashurnasirpal II (ANE 118800, XVI-XXII). Such an interpretation is by no means credited by Assyriologists, nor in the descriptions that accompany the items on the two that are currently on display in the British Museum, nor in works produced by the museum describing them (see, e.g., Mitchell 1988:46-49), nor in fact in any credible works treating these items.

${ }^{48}$ See, https://www.metmuseum.org/art/collection/search/322610. The museum's description reads: 'One suggestion is that it symbolizes the fertilization of the land through the imagery of artificial date-palm fertilization, in which male date-spathes are used to fertilize female plants. The Assyrian term for the cone, however, seems to be "purifier," and it is therefore likely that the symbolism has as much or more to do with magical protection'. Other images of winged figures hold the bucket and pine cone beside the heads of men not trees. Even Inman has an example of this from the British Museum (1875:25, fig. 7). 
'no Assyrian text discovered to date discusses the nature or purpose of this treelike thing' (Giovino 2007:1). Yet Inman felt sure he knew what the scene was about: 'the pine-cone, $=$ the testis, and the basket $=$ scrotum (?), intense emblems of the male creator', and the tree itself, "the door" whence life issues to the world', i.e., a vulva. In one of the 'sacred tree' scenes Inman reproduces, a figure is shown pointing at (actually above) the tree, which Inman identifies as 'the fist with the forefinger extended, or "the phallic hand"' (Inman 1875:126-127).

$\begin{array}{llll}M & 0 & S & t\end{array}$

significant for our discussion here are places where Inman directly associates the sun with a phallus in statements like, "The sun, being the active fructifying cause in nature, was
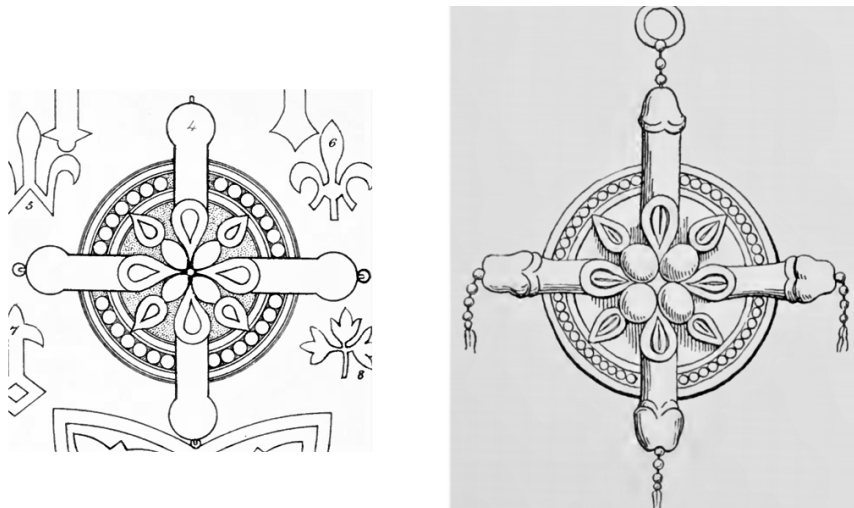

Fig. 4. L-R: Thomas Inman's and Richard Payne Knight's drawings of a phallic cross from Sant' Agata de' Goti.

generally regarded as male', 'As a male, the sun was supposed to have the emblems of virility', and 'The earth was the primitive pudendum, or yoni, which is fecundated by the solar heat, the sun, the primitive linga' (1875[1874]:113,xix,116).

Many of the things Inman asserted about phalluses and vulvas were already known to be flawed by the time his book appeared. Even more so now. And we know that Jung had some reservations about Inman's accuracy. At one point he told Freud he thought Knight's book 'better than Inman, who is rather unreliable' (F/J 159J:258). But the only clue he gave as to what he meant by unreliable is his note that Knight provided a more explicitly drawn image of a phallic cross from Sant' Agata de' Goti (Fig. 4), (F/J 162J:264, cf. Inman 1874:14-15, Pl. XI, fig. 4 \& Knight 1865:147, n. $5 \&$ Pl. XXXV, fig. 4). But whatever Jung's objections, they did not keep him from appealing to Inman's works in earlier editions of Wandlungen, although by the time the English edition of Symbols of Transformation came along, Jung removed most or all of the references to him and to Knight as well. ${ }^{49}$

${ }^{49}$ Jung himself had long been aware of the inadequacies of Wandlungen, noting that he had 'never felt happy' with the book due to its having been 'written at top speed, amid the rush and press of my medical practice, without regard to time or method', with the result that he, 'had to fling my material hastily together, just as I found it' 
Jung's discussion of Schwyzer's solar-phallus vision was not the only reference to the connection between the sun and phalli in Wandlungen. It was just one instance of a broader link he was making between the two. In that work, for example, Jung identified sunbeams as phallic symbols, and he insisted that the 'Sun's rays = Phalli' (1916:524, n. 69, 1912a:196, n. 2, 1912:247, n. 2). Further he says that when rays are shown coming off the sun like spokes, it represented a phallic wheel ('A wheel always refers to the sun') $(1916: 228,1912 \mathrm{a}: 196){ }^{50}$

It is easy to imagine that Jung's reading, and especially his reading of Inman, might have reminded him of his 1906 encounter with Schwyzer and his strange talk about seeing the sun's penis move back and forth to create the wind. Did he as a result recommend Schwyzer to Honegger as a potential candidate for research? Such might explain why Honegger singled out Schwyzer for study from among the many patients at the clinic. Perhaps Jung was trying to direct his assistant toward profitable research as he would afterward do when handing over the Honegger's papers to his later assistant C.A. Meier. In 1976, William McGuire spent an evening with Meier, who told him that 'Jung gave them [Honegger's papers] to him in the 1930's, suggesting he might do something with them' (William McGuire to K.R. Eissler, 1 Mar 1976:2, William McGuire Papers Bx 43, Fd 5; Manuscript Division, Library of Congress, Washington, DC). Meier later reported that he had attempted to follow up with Schwyzer but 'never succeeded in finding out the function of the solar phallus in his [Schwyzer's] hallucination system. During my time he no longer remembered it and his system was producing fewer and fewer fantasies' (Meier 1995:78).

Even before Honegger started his two-month stint as a volunteer at Burghölzli, he and Jung were very hopeful about discovering examples of inherited mythological symbols expressed in the delusions of the mentally ill. Schwyzer's delusion, as Jung recalled it, dovetailed perfectly with the emphases of the particular books they had been reading and discussing.

(Jung 1956, xxiii; CW 5). He had expressed concern about this at the beginning as well, remarking to Freud on 15 November 1909 on how he was 'painfully aware of my utter dilettantism' (F/J 162J:263).

${ }^{50}$ Jung writes to Emma (1 July 1910) of a new idea entering his mythological work, 'nämlich die Logoslehre des Philo Judaios'. This probably refers to the connection that Philo makes between the logos and the sun in De somniis (On Dreams) I.85 where he is interpreting Genesis 19:23-24. See, Jung 1911:215, 1912a:98; 1916:113; 1956:106. Thanks to Thomas Fischer for providing me with this reference (to the author, 2 Feb 2021). 


\section{HONNEGER'S PAPER}

J.J. Honegger presented his paper summing up his research on Schwyzer on Thursday 30 March 1910 at the Second Psychoanalytic Congress in Nuremberg, Germany. ${ }^{51}$ His was the last paper of the morning (F/J:573). The central focus of the paper was Schwyzer's view of the cosmos. Schwyzer believed he had created everything from his own seed, ${ }^{52}$ and had as the centerpiece of his cosmos an earth shaped like a flat lense (Hs 1068:17, Ms. 6 /Ts 4: die Gestalt einer flachen Linse) surrounded by a seemingly endless sea frozen around the edges, a disk floating on the aether. (Ms 1068:17, 9 (typescript 7): Die Erde liegt wie eine Scheibe auf dem Aether). This idea was really the 'big discovery' coming out of Honegger's two months of observation. When Adolf Meyer, who had been trained under Honegger's father, visited Jung and Honegger between 27 June and 5 July 1910, it was this discovery that stood out in his memory. Meyer recalls how: 'One of Honegger's patients (whom J. had analysed 3 yrs. ago without any results in this direction) gave a splendid reproduction of a Ptolemaic conception of the world with interesting detail...very much as in the creation, flat, with an edge'. (Adolf Meyer Collection, Fd VI/7/25, Alan Mason Chesney Medical Archives, Baltimore, MD). ${ }^{53}$ Schwyzer's drawing, which is, as Meyer noted, masterfully executed, still exists (Hs 1068:10 Schwyzer Erdkarta. Permission was not granted to reproduce this image). Jung also singled this out as a significant discovery by Honegger in Wandlungen and in Symbols of Transformation (Jung 1912:184 and n.2; 1912a:133 and n. 2, 1916:154 \& 511, n. 34, 1956:140 / CW 5: § 200).

In his enthusiasm for discovering proof of inherited ideas, Honegger neglected to take into account other possible influences on Schwyzer that might have had a bearing on his flat-earth views. Had he done so he might have discovered that during Schwyzer's years in England there was a very active flat-earth movement going on there. It was rooted in the 1865 book Zetetic Astronomy: Earth Not a Globe! by Samuel Birley Rowbotham

${ }^{51}$ So far as the author is aware, Honegger was the first to present an academic paper on the Schwyzer case and Jung the first to discuss it at any length in print. There are, in addition, no doctors' signatures in Schwyzer's Swiss case records from Münsterlingen or Burghölzli between the start of his second confinement in 1897 and 1910 (Verena Rothenbühler to the author, $8 \mathrm{Feb} 2021$ ).

52 The description of the cosmos runs from the $2^{\text {nd }}$ to the $10^{\text {th }}$ page of the 14 -page manuscript of Honegger's paper, and the description of the flat earth-how the sun and moon move to give the illusion of day and night work, how the disk is kept floating in space, etc.- - from the sixth to the tenth page. See, also Rank 1910:735. Rank's abstract is reproduced in Walser 1973:111, and in English in Walser 1974:253-254.

${ }^{53}$ Thanks to Sonu Shamdasani for providing me with copies of the relevant pages from Meyer's 1910 diary. 
writing under the pen name 'Parallax'. The movement was forcefully continued under John Hampden, who loved stirring up controversy with prominent evolutionists, and gave birth in 1893 to the Universal Zetetic Society, which had its own magazine called The Earth is Not a Globe Review (For the history of the movement, see Garwood 2007).

More generally, Honegger might have pursued the possible significance of Schwyzer's regular references to the Freemasons, a group much taken up with mythological symbolism and with trying to prove their antiquity by seeking parallels in the texts and symbols of world religions and mythology. Sometimes, as we have already seen in the case of Geoffrey Higgins, they presented Freemasonry as at one with, or standing behind, the ancient religions. As a child Schwyzer had lived in the same house with a family by the name of Scherer (Hs 1068:18, 1). The father was apparently the president of the local masonic lodge. Schwyzer claims he had encountered the Freemasons in England as well and was actually made a Freemason himself as he lay in the hospital after shooting himself in the head (Hs 1068:18, 2). It is difficult to distinguish between reality and fantasy in what Schwyzer says about the Freemasons and the Scherers. For most of his life he had been obsessed with Marie Scherer, one of the daughters of the family, whom he described as holding all the secrets of freemasonry (Hs 1068:18, 1: Sie habe das ganze Freimaurergeheimnis in d. Hand). Schwyzer was never able to bring himself to express his life-long love for the girl. So when Marie eventually became engaged to a certain doctor (Hs 1068:18, 3, [10]), ${ }^{54}$ Schwyzer's second break down quickly followed. Schwyzer came to view the Scherers as a mostly malevolent cosmic power. They were the gods of the Freemasons, and everyone surrounding him was controlled by them (Hs 1068:17, Ms 14,12/Ts 11,910). If they were young with brown eyes, it was Marie looking out at him, if grey eyes, then her sister Lydia, if elderly, then old mother Scherer (Hs 1068:17, Ms 12/Ts 9-10). According to Schwyzer, it was the Scherers who tricked astronomers into believing that the moon has mountains (Hs 1068:17, Ms 7/Ts 5).

\footnotetext{
54 The second-mentioned passage is dated March 1898. In his 4 June 1907 letter to Freud (F/J 29J:57), Jung confuses Marie with her sister Lydia. This implies that Jung was not intimately aware of the details of Schwyzer's case, since the latter seems to have spoken of Marie very frequently (e.g., as in Hs 1068:[10]: 'Das Marieli von dem er so oft spreche'). The mistake also suggests that Jung did not read Schwyzer's case history carefully when preparing his letter to Freud. Had he done so he would have discovered that Schwyzer did not even like Lydia. According to Schwyzer everything Lydia did was unpleasant, but everything Marie did was pleasant (Hs 1068:18, 5, dated 7.10.1901).
} 
Honegger's paper says nothing about the sun having a phallus. Indeed, neither the words 'penis' nor 'phallus' appear in the manuscript. Mention is made, however, of the sun having an 'upright tail' (Aufwärtsschwanz), but, as we shall see in a later section, in the context it was a ray of light not a phallus. Jung took over the word Aufwärtsschwanz, and gave it a new meaning after reading Dieterich's Mithrasliturgie a few months after Honegger gave his paper. We shall have a good deal more to say about Honegger's paper as we proceed.

\section{THE MITHRASLITURGIE (MITHRAS LITURGY)}

Even though Jung stressed the similarly, indeed near identity, between Schwyzer's 1906 experience and a passage in the Mithrasliturgie, when one actually compares the strange arcane language of that passage with what Jung describes Schwyzer saying or doing, it hardly seems obvious that the two are as closely related as he seemed to think. Here is the passage as presented in Hans Dieter Betz's recent critical edition of the Mithrasliturgie (Mithra's Liturgy) into which I have inserted in two places the original Greek word and Dieterich's German translations in parentheses (Brackets Betz's):

Now the course of the visible gods will appear through the disk of god, my father; and in similar fashion the so-called pipe (aulos/ Röhre), the origin of the ministering wind; for you will see it hanging from the sun-disk like a pipe (aulos/Röhre). From the region of the west [it is the source of] the unending east wind, ${ }^{55}$ when it is assigned to the region of the east, and in the same way the other [west wind going] toward the regions of that one [scil., ${ }^{56}$ the east]. ${ }^{57}$ Then you will see the turn-about of the image [scil., the pipe]. And you will see the gods (Betz 2005:52). ${ }^{58}$

While we certainly see similarities between what is said here

\footnotetext{
${ }^{55}$ Meyer reads: 'You will see the outflow of this object toward the regions westward, boundless as an east wind' (Betz 1986:49).

${ }^{56}$ Scil. = scilicet: 'namely'.

${ }^{57}$ Meyer: 'if it be assigned to the regions of the East-and the other (viz. the west wind), similarly, toward its own regions'.

58 The English translation of the Mithras liturgy by theosophist G.R.S. Mead, which Jung was also familiar with and quoted from in Wandlungen, also translated aulos in this passage as 'pipe' (Mead 1907:22, cf. Jung 1911: 212)
} 
and what Schwyzer saw, there is nothing approaching 'word for word' correspondence as Jung occasionally suggested (Jung 1929:111 / CW 8:§228 \& 1935:42 / CW 18:§85).

There are of course some obvious differences between the passage and how Jung describes the Schwyzer incident. The pipe (phallus?) hangs down rather than stands erect. The wind presumably comes through the pipe rather than from the pipe's moving back and forth stirring the air. But these are superficial issues compared to a more essential but less obvious difference. Jung is taking the word translated 'pipe' here and 'Röhre' in Dieterich (1910:7) to be a euphemistic reference to a penis. But that is by no means obvious from the text. Indeed in the edition quoted above, the editor, Hans Dieter Betz, actually pokes fun at Jung for suggesting it: 'Fantastic is Carl G. Jung...for whom the hanging pipe iswhat else?-a phallus' (Betz 2005:143n. 311). Even in English the more obvious interpretation is that the Sun is presented to the initiate as playing a musical instrument, a pipe.

But beyond this, the Greek word aulos, translated 'Röhre' and 'pipe' casts even more definitive doubt on Jung's interpreting the word as referring to a penis. To be sure, the German word 'Röhre' can be taken as

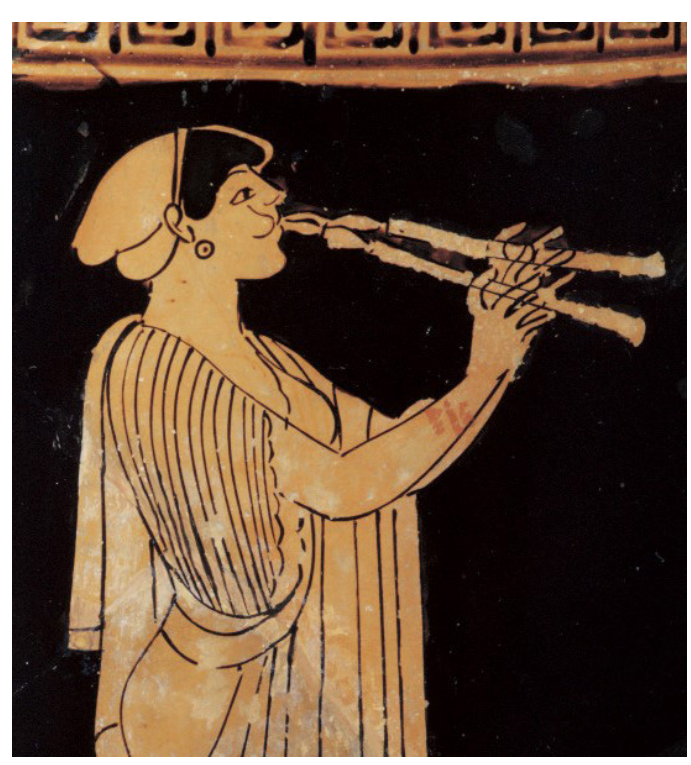

Fig. 5. Girl playing aulos, Terracotta lekythos (oil flask). Attributed to the Brygos Painter, ca. 480 B.C. (Courtesy Metropolitan Museum of Art, New York). a euphemism for a penis (Küpper 1982-1984:6.2329). But the situation is different with the underlying Greek term aulos.

There are a number of Greek words that were used in antiquity to refer to the male member, from the discrete and respectfully descriptive aidoion (See, e.g., Herodotus, Histories 2.30.4 48.2-3, Aristotle, The History of Animals 7.3 (583b) and 10.5 (637a)) and phallos (Herodotus, Histories 2.48.2), to the crude peos (Aristophanes, Clouds 7734; Lysistrata, 415, 928, 1012; Women at the Thesmophoria 62). Other terms invited usage as intentional double entendres, including kerkos (tail) (Aristophanes, Women at the Thesmophoria, 239), schoinion (rope) (Aristophanes, The Wasps, 1342), and pragma (thing) (Aristophanes, 
Clouds 195-197). In his book, The Maculate Muse, Jeffrey Henderson provides a veritable lexicon of the Greek euphemisms and obscenities used in Attic Comedy, and dedicates an entire chapter to male and female sexual organs (1991:108-130). Significantly the word aulos only appears once in the book, and that referring not to a phallus but to the potential usefulness of the musical instrument called an aulos for making fart sounds and other obscene noises to accompany the bawdy antics of actors on stage (1991:198).

The reason aulos is not a natural choice in Greek to be used to refer to the male organ is that it not a single pipe. It was the double-piped musical instrument that we see depicted everywhere in Greek and Roman art (Fig. 5). As John G. Landels explains,

In the woodwind category there was one instrument which spanned the whole history of Greek and Roman music, and which appears more commonly in illustrations than any other-a double, reed-blown pipe, called aulos in Greek and tibia in Latin. For many years it has been the practice of Classical translators, including some very distinguished ones, to use the word 'flute' for this instrument. This is extremely misleading and inaccurate... the aulos did not look like a flute; it was a double pipe, the two pipes being held out in front of the player. (Landels 1999:24).

Landel's criticism of Classical translators rendering aulos as 'flute' can also be leveled against standard Greek lexicons over the last three centuries. Wilhelm Pape's Griechisch-deutsches Handwörterbuch, which Jung owned and used in this connection, defined aulos as a wind instrument, but especially as a flute that differed from ours by having a mouthpiece and a deeper tone (cf. Pape 1849:1,353 and Jung 1931:151 / CW 8:§318). Pape’s entry followed closely the earlier definition given in Franz Passow's Handwörterbuch der griechischen Sprache (18191824) ${ }^{59}$ which later became the basis as well for the authoritative Liddell,

${ }^{59}$ Pape: '...jedes Blaseinstrument, bes. die Flöte...von unserer Flöte sowohl durch dass eingesetzte Mundstück ( $\gamma \lambda \omega \sigma \sigma i \varsigma)$, als durch den stärkeren, tieferen, Ton verschieden'. / Passow: '...jedes Blasinstrument, bes. die Flöte, die aber wieder mehrere Unterarten hatte, und sowohl wegen ihres wie beym Hoboe eingesetzten Mundstückes, als wegen ihres tieferen, volleren und stärkern Tons von unsrer Flöte wesentlich verschieden zu denken ist.' / Early editions of Liddell and Scott: '.... any wind instrument, mostly rendered a flute, though it was more like an oboe, as well from its having a mouthpiece, as from its fuller deep tone'. Later editions of the latter would add 'clarionet' and eventually drop 'oboe'. The situation has not improved in the interim. G. W. H. Lampe's A Patristic Greek Lexicon (1961) gives pipe, flute, as its first definition and 
Scott, Jones, A Greek-English Lexicon (LSJ), whose earlier editions simply repeated Passow's definition. The current magisterial $9^{\text {th }}$ edition of Liddell, Scott, Jones (1940) still inadequately defines aulos as 'pipe, flute, clarionet'. ${ }^{60}$

Feeling the inadequacy of both 'Röhre' and 'pipe' as translations of aulos in the Mithrasliturgie, the author decided to pursue the question with Stefan Hagel of Vienna's Institute for the Study of Ancient Culture of the Austrian Academy of Sciences. Hagel is the author of Ancient Greek Music. A New Technical History (Cambridge University Press, 2009), and he is also associated with the European Music Archaeology Project. Had Hagel ever heard aulos being used in reference to the male member? 'This was the view of Carl Jung in interpreting a text (Mithras Liturgy)', I wrote, 'but I have been doubtful of it precisely because the aulos is usually double-piped'. Hagel responded:

I agree that a phallic interpretation makes little sense for double pipes. I have always wondered whether the quasi-restriction to double pipes might be due also to the requirement of avoiding phallic connotations ... After all, one of the very few texts on the monaulos [that is to say mono-aulos, single aulos], Martial Epi[grams]. [14]. 64, famously exploits precisely that association. ${ }^{61}$

When the Mithras Liturgy uses the term aulos to refer to the musical instrument the sun is playing the intended reference is almost certainly to the then universally familiar double-piped wind instrument and not to a phallus. As such the ancient text simply cannot represent an inconspicuously meaningful symbolic parallel to Schwyzer's reference to the sun's having a phallus in 1906.

tube as its second and only alternative, and even the $3^{\text {rd }}$ edition of BDAG, i.e., Bauer, Danker, Arndt, Gingrich's authoritative A Greek English Lexicon of the New Testament and Other Early Christian Literature (2000) offers only flute.

60 Jung did not own Passow's Handwörterbuch. Thanks to Thomas Fischer for information on lexicons in Jung's library.

${ }^{61}$ Electronic response (26 Sept 2018) at http://www.doublepipes.info/pipesinstruments-singulars-or-the-plural/. Martial's epigram, entitled 'Tibiae', reads as follows: Ebria nos madidis rumpit tibicina buecis; saepe duas pariter, saepe monaulon habet // 'The drunken flautist bursts our ears with her bibulous cheeks; often she uses two pipes at once, often only one' (ET: Walter C.A. Ker). 


\section{A TUBE FROM HEAVEN}

Jung believed that the similarity between what Schwyzer saw and the content of the passage from the Mithrasliturgie was so striking as to place it beyond dispute (Jung 1931:151/CW 8: § 319). Still, to remove any remaining doubt, he felt it was important to provide a third, similarly striking parallel to both. He felt sure he had found it in an obscure medieval artistic motif in which the conception of Jesus ${ }^{62}$ is 'represented by a tube [Röhre] or pipe [Schlauch $]^{63}$ coming down from heaven and passing beneath the robe of Mary. Into this flies the Holy Ghost in the form of a dove for the impregnation of the Mother of God' (Jung 1912a:94, 1952:11 / CW 5:§150, 1991:95 / CW Supp. Vol. B:§172).

Jung included mention of this pictorial motif in several of his accounts of the Solar-Phallus story (see also Jung 1931:151 / CW 8:§319, 1934:52 / CW 9.I: $\$ 108$. In the last-mentioned account, it is 'the dove or the Christ-child' that comes down the tube). But he gave no details, not even any indication where such a picture might be found, until Symbole der Wandlung, the 1952 revision of his 1911/1912 Wandlungen und Symbole der Libido. In Symbole der Wandlung two obscure paintings were presented to illustrate the motif spoken of in the passage (Plates III and VIII in Jung 1956: between $274 \&$ 275). These examples were chosen not by Jung but by Jolande Jacobi. Three hundred pictures chosen by her were included in the original 1952 edition of Symbole. This is indicated on the title page of that edition. ${ }^{64}$ The German edition for the Gesammelte Werke also acknowledged that Jung had entrusted the task of gathering pictures to his 'proven colleague' Dr Jolande Jacobi (Jung 1973:8). Unfortunately, the English editors, gave no indication who chose the pictures.

What are now Plates III and VIII were specifically linked to the passage under consideration in the 1952 edition (Jung 1952:168). The images do not appear with their traditional titles in any of the editions, but have been provided with freshly minted ones presumably by Jacobi or Jung. And even though both pictures include what might be mistaken for a tube

\footnotetext{
${ }^{62}$ Originally Jung incorrectly referred to the the virginal conception of Jesus as the 'conceptio immaculata', which actually refers to the Roman Catholic teaching of the sinless conception of Mary (Jung 1911:211, 1912a:94, 1916:108, 1991:95). The error was later corrected (Jung 1952:167, 1956:101 / CW 5:§150).

63 'Pipe' was changed to 'hose-pipe' to translate Schlauch in Jung 1956:101 / CW $5: \S 150$.

64 'Mit 300 Illustrationen, ausgewählt und zusammengestellt von Dr. JOLANDE JACOBI'.
} 
or pipe, neither actually has anything to do with a tube coming down from heaven and up under the Virgin's robe. After our discussion of what these two Plates actually depict, we shall suggest what we suspect was probably the actual image Jung had in mind when he initially spoke in Wandlungen of a pictorial parallel to Schwyzer's vision and the Mithrasliturgie.

\section{PLATE III/ABBILDUNG 4 (JUNG $1952=$ ABBILDUNG 19).$^{65}$}

The first plate is labelled Christus im Scho $\beta$ der Jungfrau / Christ in the Virgin's Womb, dated c. 1400, and attributed to an Upper Rhenish Master (Jung 1952:81/1956: between $274 \&$ 275). The picture was taken from a coffee-table Christmas picture book entitled Das Christgeburtsbild der frühen Sakralkunst (1939) by the pious Austrian painter Aloys Wachlmyer, who is better remembered as Aloys Wach a minor player in German Expressionism in his youth (Guenther 1991:1-4; Wachlmyer 1939:11-18). The name Wachlmyer gave the picture on his plate list in the back of his book was Maria in ihrem Hause (Mary in her house).

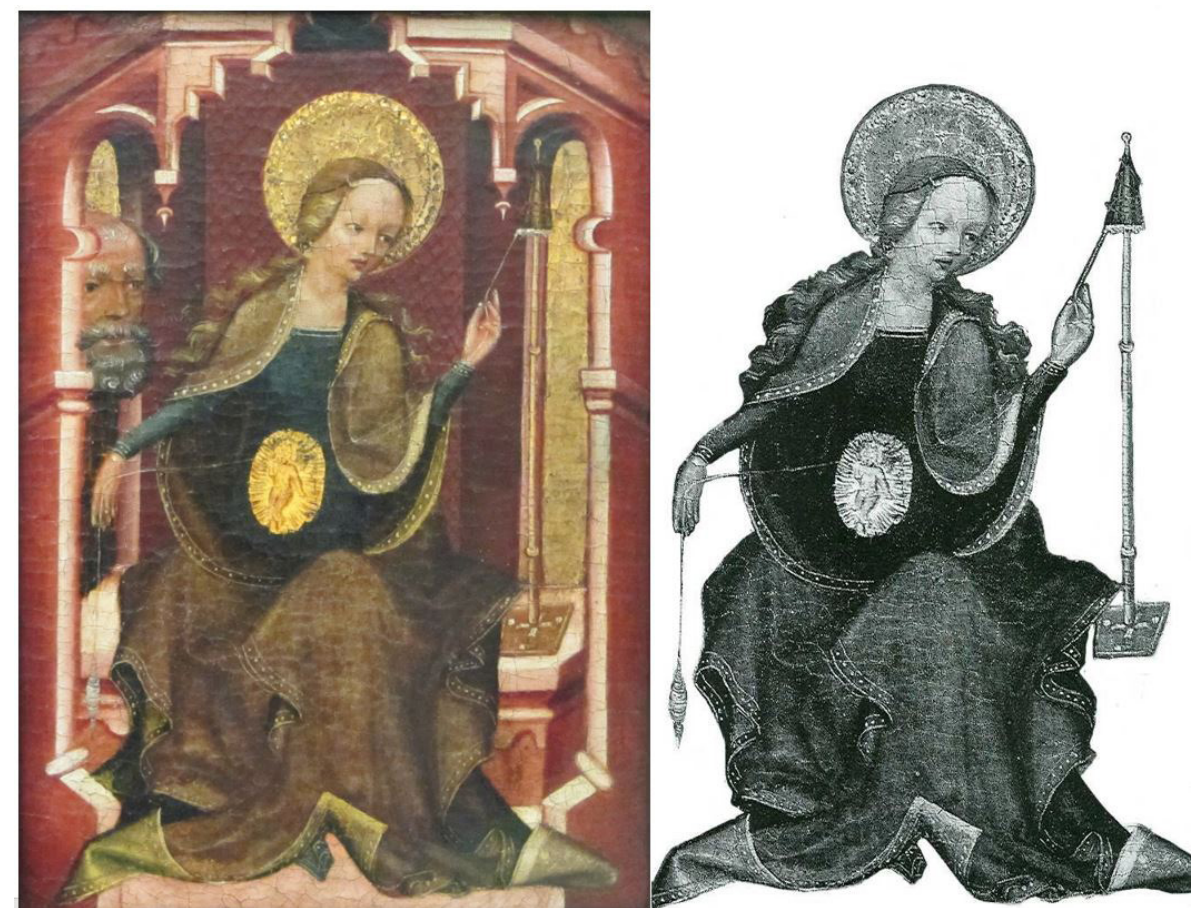

Fig. 6. 'Joseph's Doubts' motif with the pregnant Virgin working her spindle and distaff. The painting is called Maria am Spinnrocken at Berlin's Staatliche Gemäldegalerie, where it resides, and attributed to a Nuremberg or Bohemian master (c. 1410).

\footnotetext{
${ }^{65}$ I give first the plate number in volume 5 of Jung's English Collected Works (258259), then that of volume 5 of his Gesammelte Werke (71), then finally the 1952 original German edition (81).
} 
In the picture we see the Virgin placed in an architectural setting with the child Jesus not so much in as in front of the Virgin's womb and framed by an aureole of gold behind him. The aureole is a common artistic convention for depicting Jesus in Mary's womb referred to as a mandorla (Italian: 'almond'). Upon initial inspection, we see what might be taken for the tube Jung was referring to coming down from the top right side of the picture, passing through the Virgin's hands and then dropping down to the left at the bottom of the picture. As it passes between Mary's hands it also seems to go in front of/through/behind the baby Jesus.

But what we are actually seeing is not a tube. The title given the picture on its accompanying plaque in Berlin's Staatliche Gemäldegalerie, where it currently resides, clarifies the matter: Maria am Spinnrocken. What we are actually seeing is yarn being spun by the Virgin, coming down from the top of her distaff on the right, where the unspun fibers of flax or cotton or wool have been affixed, and being twisted into yarn by the Virgin with the aid of her spindle, which is suspended on the left toward the bottom (Fig. 6).

Depictions of Mary spinning are extremely common in the iconography of both Eastern and Western Christendom. The motif had its origin in the second-century Proto-Gospel of James 10-11 where the youthful Mary was chosen to spin scarlet thread for the curtain of the Jerusalem Temple, which she was doing when the Angel Gabriel arrived with his announcement that she was to give birth to Jesus.

In the Eastern Church it became standard for Mary to be holding a spindle and thread in icons of the Annunciation, but normally the spindle only, not the distaff (Nes 2000:39 \& Ouspensky 1982:172). According to the Hermeneia, or 'Painter's Manual' of Dionysius of Fourna, an eighteenth-century iconographer from Mount Athos Monastery in Greece, the Virgin is to be shown 'standing before a chair, with her head slightly bowed; in one hand she holds a spindle with a roll of silk thread upon it, while she stretches out her right hand towards the archangel Gabriel who stands before her' (Dionysius of Fourna 1996:32). There are exceptions

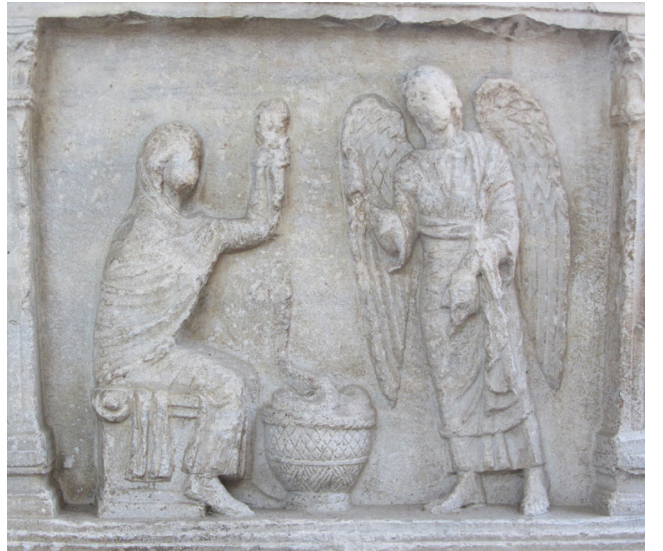

Fig. 7. Annunciation, Pignatta Sarcophagus, Ravenna, Italy, 4th-5th cent. 
to the spindle-only rule in the East, as is seen, for example, in a $10^{\text {th }}$ century picture from the icon gallery of the Church of Saints Clement and Panteleimon in Ohrid, Macedonia (Babić 1985:17). In addition, one of the earliest depictions of the Annunciation on the $4^{\text {th }} / 5^{\text {th }}$ century Pignatta Sarcophagus in the garden next to Dante's tomb in Ravenna also showed Mary with her spindle and distaff (Fig. 7). ${ }^{66}$

In the West, however, depictions of Mary's spinning eventually came to be replaced or supplemented in Annunciation scenes with her reading a Bible opened to Isaiah 7:14, the passage that features the prophetic words relating to herself: 'Behold, a virgin shall conceive, and bear a son, and shall call his name Immanuel' ${ }^{67}$

However, Plate III does not depict an Annunciation scene. It is not about the conception of Jesus. The overly large face peering into the window on Mary's right, with bald head and grey hair, is not the angel Gabriel but Mary's husband Joseph. In the Proto-Gospel 9-13 and its Latin counterpart, the $7^{\text {th }} / 8^{\text {th }}$ century Gospel of Pseudo-Matthew 8-10, the elderly Joseph is away on a building project when the annunciation occurs and only returns later to discover to his dismay that Mary is well along in her pregnancy. He doubts her purity and reproves her. So, besides Maria am Spinnrocken, this picture is also described as a 'Joseph's doubts' scene (Gibson 1989:168) ${ }^{68}$ The Joseph's doubt motif is not especially common in paintings, but it was a regular feature in Medieval English Mystery Plays. ${ }^{69}$

Other examples which combine the Joseph's doubt motif and

\footnotetext{
${ }^{66}$ For other early examples see Taylor (2013:25 fig. 4 \& 26, fig 6). Taylor writes concerning the Pignatta Sarcophagus that 'there appears to be a distaff held under her left arm and a thick fiber rove' (32). She may be correct but this author remains uncertain.

${ }^{67}$ See, e.g., Gibson (1990:47) who dates the shift to the beginning of the $13^{\text {th }}$ century in the west (c.f. Robb 1936, 485, n. 21). More recently, however, Miles has provided examples that the motif as early as the $9^{\text {th }}$ century (The Brunswick Casket), noting that by the 'the late twelfth century the Reading Annunciate had completely pervaded the Western artistic tradition' (2014:643, fig. 1 \& 668). The Isaiah 9:6 passage can be seen with particular clarity in Matthias Grünwald's Annunciation from the Isenheim Altarpiece c. 1510-1515 (see, e.g., Pelikan 1996: among the unnumbered plates following p. 128).

${ }^{68}$ Referring to the same motif, Rosenau (1944, Pl. I.C) calls the picture 'Joseph Reproves the Virgin'.

69 The Townely Play, no. 7e.; N-Town Play, no.12; The York Corpus Christi Play, no. 13. All accessible at https://d.lib.rochester.edu/teams/text-online/. See, further, Gibson 1975 \& 1989, Cf. Flanagan 1996. It is perhaps no surprise that Gibson chose this picture for the cover of her 1990 book.
} 
Mary working at her distaff and spindle can be cited, ${ }^{70}$ but particularly ubiquitous in church decorations, paintings and holy cards of the $19^{\text {th }}$ and $20^{\text {th }}$ centuries, are scenes representing the Holy Family that show Mary
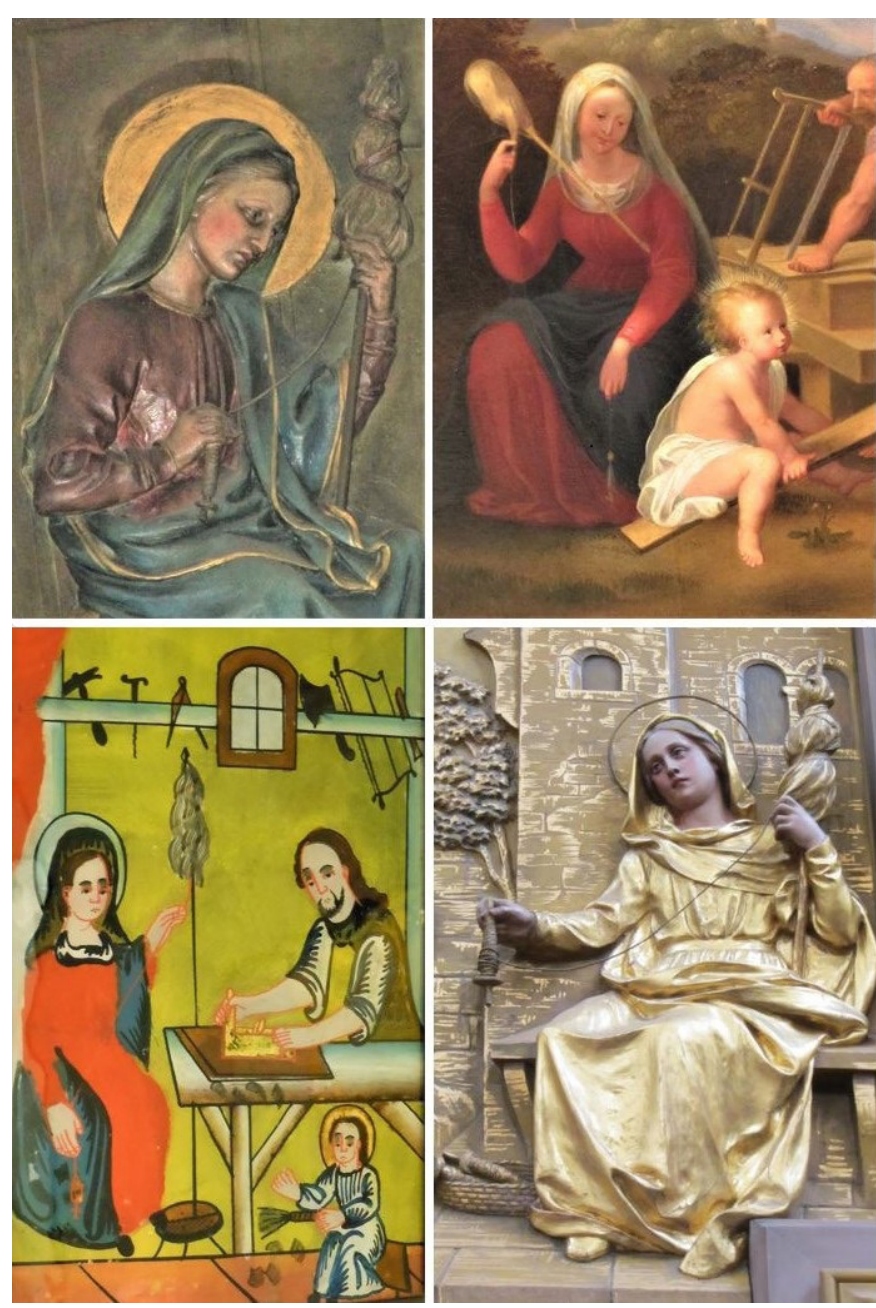

Fig. 8. Holy Family Scenes from Graz, Austria, showing Mary using a spindle and distaff. L-R, T-B: (1) Loretokapelle, Garisonskierke (c. 1888), (2) Joseph Ritter von Hempel, 'Das Christkind auf der Schaukel' ('The Christ child on a seesaw') (1850), Neue Galerie, (3) 19th century painting on glass, Volkskundemuseum, (4) Josefskirche (1908). spinning with spindle and distaff, Joseph working at his carpentry, and the child Jesus either playing or helping Joseph. Indeed, the Roman Catholic Church the author attended as a small child in the American West, which was dedicated in 1915, had a stained-glass window with this scene, as did the new Church built to replace it in 1963, this time with windows designed by Gabriel Loire. ${ }^{71}$

When seeking illustrations of the ubiquity of this theme it occurred to the author to keep an eye out for local expressions of it in Graz, Austria, where he happened to be at the time. Without much trouble he came across four. Two carved relief panels, one in the Loretokapelle in the

\footnotetext{
${ }^{70}$ For example, a small $15^{\text {th }}$ century diptych at the Abtei Nonnberg in Salzburg, Austria (Gibson 1989, 167, fig. 6:13), and a fresco on the North wall of the sacristy door in the Urbanskirke in Schwäbisch Hall, Baden-Wurttemberg (Rossner 2012).

${ }^{71} \mathrm{https}$ //www.ateliers-loire.fr/en/gabriel-loire-usa-washington-clarkston-holy-familyparish-catholic-church.php.
} 
Garisonskierke (c. 1888) and the other in the Josefskirche on Schönaugürtel (1908). ${ }^{72} \mathrm{He}$ also found a very charming $19^{\text {th }}$ century painting on glass in the Volkskundemuseum, Graz, and lastly a sentimental scene in the Neue Galerie entitled Das Christkind auf der Schaukel ('The Christ child on a seesaw') (1850), by the Austrian artist Joseph Ritter von Hempel (Fig. 8 ). Since the distaff and spindle represent one of the most common and ancient domestic technologies, it is surprising that a picture of it came to be confused with a tube coming down out of heaven to impregnate the Virgin. And perhaps more surprising still, given the fact that a photograph exists of Toni Wolff, an intimate of Jung, holding a distaff and spindle (Healy 2017:149, fig. 50).

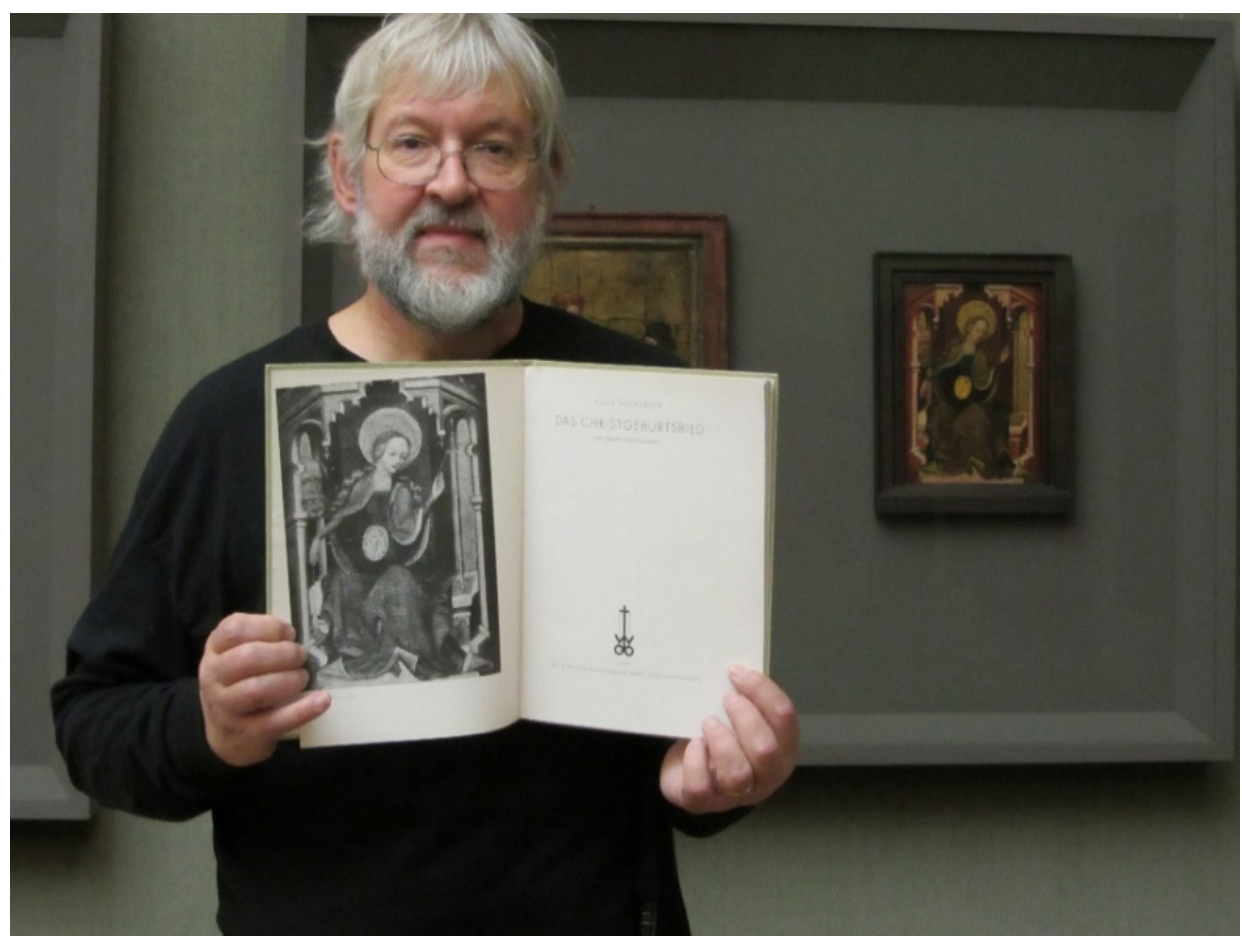

The author at the Staatliche Gemäldegalerie, Berlin, with Alois Wachlmyer's Das Christgeburtsbild (1939), the source of Plate III in Symbols of Transformation, and the original in the background (Photo: M. Huggins).

\section{PLATE VIII/ABBILDUNG 17 (JUNG $1952=$ ABBILDUNG 50) ${ }^{73}$}

Plate VIII is labelled Die Obumbratio Mariae in the German editions of Symbole, which is translated in the English as The Overshadowing of ${ }^{72}$ Bartholomäus Peter Neuböck (Figuralbildhauer), Bartholomäus Gorendschek (Jernej Gorenček) (Ornamentbildhauer), and Wilhel Sirach (Vergoldemeister).

${ }^{73}$ CW 5:258-259 / GW 5:134 (Jung 1952:168). 
Mary (Jung 1952:168, 1973:134, cf. 1956:274-275). The title no doubt refers to the Latin Vulgate reading of the Gospel of Luke chapter 1 verse 35, where the angel Gabriel tells Mary that 'The Holy Spirit shall come upon thee, and the power of the Most High shall overshadow (obumbrabit) thee.' In the picture we see several people, buildings, objects and animals with Latin labels, and what appears to be a strait tube-like line coming down from heaven onto Mary's head. The tube might then seem to continue around behind her shoulder and then to bend and pass through her hands. There is also some sort of small animal at her knee that at first looks like a dog. But the picture is really too small to get a clear idea of what is going on.

In the German editions the picture is misidentified as a late $15^{\text {th }}$ century Wirkteppich (i.e., a tapestry), in the Bayerisches Nationalmuseum in Munich. The caption in English describes it as a 'Tempera painting on wood, Erfurt Cathedral, 1620-40', which is more correct. It is a painting and it is at Erfurt. ${ }^{74}$ The origin of the error in the German edition is not a mystery. Tafel 42 in the second part of Karl von Spiess's Marksteine der Volkskunst, which was the source for this image, contains two pictures. The captions for both are at the bottom of the page. The German editions of Symbole simply took over the wrong caption (i.e., that of fig. 113 instead of fig. 112) (Fig. 9).

Von Spiess does not give the picture a name but rather includes it

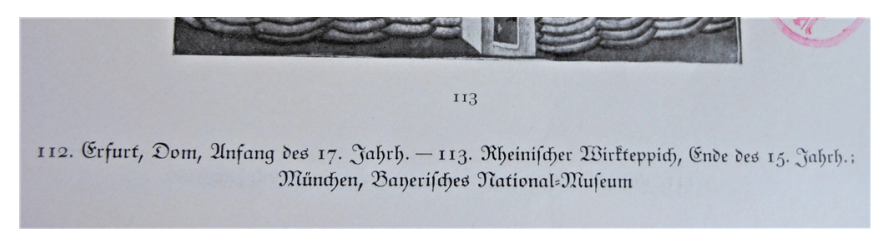

Fig. 9. Caption from Tafel 42 of the second part of Karl von Spiess's Marksteine der Volkskunst. among more than a dozen other examples of the same motif. However, we can discover what it is

from one of the few Latin labels we can actually clearly see in the center at the bottom of the picture as it appears in Symbole: Hortus Conclusus. Once we have the name, we also know that what seems to be passing through the Virgin'shandsisnotatubecoming downfromheaven, butahornthat isattached to the animal at Mary's knee, which turns out to be not a dog but a unicorn.

The Hortus Conclusus theme represents a curious amalgam of standard symbols and themes of late medieval devotion drawn from the allegorical interpretation of items in the Old Testament thought to refer to the Blessed Virgin Mary (see examples in Labriola \& Smeltz 2002). The words Hortus Conclusus comes from Canticle of Canticles 4:12 which reads in the Latin Vulgate: Hortus conclusus soror mea, sponsa, hortus

${ }^{74}$ In the Diözesankunstmagazin. Dated more recently to the second quarter of the $16^{\text {th }}$ cent. by Beker-Lamers 2003. 
conclusus, fons signatus, 'A garden enclosed is my sister, my spouse, a garden enclosed, a fountain sealed up'. The passage was taken to refer to Mary's perpetual virginity ante-partum, in-partu, and post-partum, that is to say, before, during, and after, the birth of Jesus. The $4^{\text {th }}$ century writer Saint Jerome, who was really the architect of the Catholic perpetualvirginity doctrine, had already understood this passage and its terminology as prefiguring the perpetually virgin Mary, and it continued to be so understood throughout the Middle Ages. ${ }^{75}$ In addition, there are two other primary motifs in Hortus Conclusus scenes, which are unusually, even inexplicably, combined. The first is the Annunciation, in which Gabriel tells Mary that even though she is a virgin she is going to bear a son, a scene most often accompanied by a ray (or rays) from heaven along which the Holy Spirit and/or the child Jesus is seen descending. When the rays had a clear termination point it was usually on Mary's head, as in the picture under discussion. This detail is found not only in Hortus Conclusus scenes but in almost all Annunciation scenes.

The second theme was a mystic unicorn hunt, which ultimately derives from the Physiologus, a $3^{\text {rd }}$ or $4^{\text {th }}$ century work in Greek that stands behind the various Medieval Bestiaries. According to the Physiologus: ${ }^{76}$

The hunter cannot approach [the monoceros or unicorn] because he is extremely strong. How do they hunt the beast? Hunters place a chaste virgin before him. He bounds forth into her lap and she warms and nourish the animal and takes him into the palace of kings. (chap. 36, Physiologus 2009, 51).

Out of this passage was born a common pictorial theme depicting a unicorn laying its head in the lap of a virgin. The theme was often combined with the idea of the unicorn hunt, in which the unicorn is not led off to a palace but speared by the hunter while its head lay in the virgin's lap. When the theme came to be combined with the Annunciation in Hortus Conclusus scenes Gabriel was duly transformed into a hunter blowing his horn with four hunting dogs, named, in this case from top to bottom, Justice, Truth, Mercy, and Peace (Iustitia, Veritas, Miseracordia, and $P a x$ ). The dogs' names represent an intentional allusion to Psalm 84:11 of the Latin Bible (85:10 in current editions): "Mercy (miseracordia) and truth (veritas) have met each other: justice (iustitia) and peace (pax) have

\footnotetext{
$\overline{75}$ Jerome, Against Jovianus 1.31 and Letter 48.20 (to Pammachius).

${ }^{76}$ On the origin and date of the Physiologus see, Scott (1998).
} 
kissed' ${ }^{77}$ And instead of Gabriel's words from the Latin edition of Luke 1:28 Ave Gratia Plena ('Hail Full of Grace') coming from his mouth, they proceed in Hortus Conclusus scene out of the end of his hunter's horn. The rest of the items in the picture follow standard Medieval allegorical understandings of Old Testament items prefiguring the Virgin Mary as shown in Figure 10. The combination of Hortus Conclusus and Unicorn Hunt motifs was relatively short lived, perhaps because of the Council of Trent's 1563 call for the abolition of images suggestive 'of false doctrine, and furnishing occasion of dangerous error to the uneducated'. ${ }^{78}$

Like Plate III, Plate VIII does not represent an example of the motif Jung was describing. Out of the several examples of the Hortus Conclusus images in Karl von Spiess's book in the section dealing with this motif, we may wonder why Jacobi chose this particular image? ${ }^{79}$ One item that might have commended it to her is the ruler-straight line coming down from heaven, which could easily be taken for a tube, and then the illusion that makes it seem to bend and pass through the Virgin's hands when the identity of the animal at her knee is not properly grasped. Yet the straight white tube-like line that is so striking in von Spiess, and by extension in

\footnotetext{
77 The special significance of this passage to the present context comes from a sermon featuring it on the Feast of the Annunciation in 1140 AD by Saint Bernard of Clairvaux. In the sermon, Bernard presented a parable that became widely known and endlessly retold in sermons, books, plays, and art throughout the remainder of the Middle Ages. Bernard tells of a debate over the fate of humanity between God the Father and his four daughters, Justice, Truth, Mercy, and Peace (Iustitia, Veritas, Miseracordia, and Pax). In the beginning, Bernard says, humanity was clothed in these four virtues. But they lost them in Eden's fall. Mercy and Peace appealed to God the Father for some means of human redemption and forgiveness to be found, a proposition which Truth and Justice firmly rejected. In response God proposed this resolution. If an innocent person would be willing to die on behalf of fallen humanity, whose willingness stemmed from love, death would be bound and humanity saved. Truth and Mercy went forth in search of such a person on the earth. Naturally no one was found, and when they returned from there, they were scolded for failing to realise that only the one who had proposed the plan, God himself, was worthy to fulfill it. So God calls Gabriel to go to the virgin and make his announcement. God tells Truth and Mercy to go before the incarnating Christ, Justice to get ready his throne, and Peace to accompany him. See, Bernard of Clairvaux, 'In Festo Annuntiationis Beatae Virginis', Patrologia Latina 183.383-390. The story is summarised in English in Traver 1907:16-17. See further, the lengthy poetic rendering of the story in John Lydgate's $15^{\text {th }}$ century Middle English Life of Our Lady, where we also find the theme of Christ as Unicorn being pacified by the Virgin Mary (Lydgate 1961:333-35).

${ }^{78}$ Council of Trent, 25 $5^{\text {th }}$ Sess. (Dec. 3, 1563), (Schaff 1993:2,203).

${ }^{79}$ None of the other examples presented in von Spiess shows a tube coming down and going under Mary's robe. Von Spiess includes a general list of the items one would expect to find in pictures of this type (von Spiess 1942:114).
} 
Symbole der Wandlung and its English counterpart actually represents an enhancement. In the original painting the line or beam is much less clearly defined and ephemeral, and even seems to dissipate somewhat before reaching the Virgin's head. ${ }^{80}$

Jung was already familiar with the theme of the Virgin-tamed unicorn in its connection to Hortus Conclusus pictures when he originally wrote Wandlungen: 'The unicorn is hunted by the archangel Gabriel, and driven into the lap of the Virgin, by which was understood the immaculate conception [sic]' (Jung 1916:525, n. 11, = 1912:257-258 n. 2 and 1912a:206207). This statement was not carried over to Symbols of Transformation (Jung 1956:214 / CW 5:§314, cf. 1916:525 n. 11). But another one like it is retained from Wandlungen and specifically linked to Plate VIII showing that Jung (or Jacobi) was aware that the animal at Mary's knee in the picture was a unicorn: 'In Christian picture-language the unicorn, as well as the dove, is a symbol of the spermatic Word or Spirit' (Cf. pl. VIII.)' (Jung 1956:321 / CW 5:§492, cf. 1916:335, 1912:356, 1912a:305). The words 'picture language' were added to what Jung had originally written, perhaps as a way of connecting the remark more directly to the picture in Plate VIII'. ${ }^{81}$ Jung also now introduces a footnote directing his readers to the very extensive discussion of the symbolic significance of the unicorn, including the Hortus Conclusus theme, in Psychology and Alchemy (See esp. Jung 1968:435-448 / CW:518-526 \& 1972:495-510 / GW:518-526).

\footnotetext{
80 https://www.flickr.com/photos/28433765@N07/5685963259/in/ album-72157623030373555/.

81 'It is well known that, in addition to the dove, the unicorn is also a procreative symbol of the Logos' (Jung 1916:355) // Bekanntlich is außer der Taube auch das Einhorn ein zeugendes Symbol des Logos (Jung 1912a:305; 1912:356).
} 


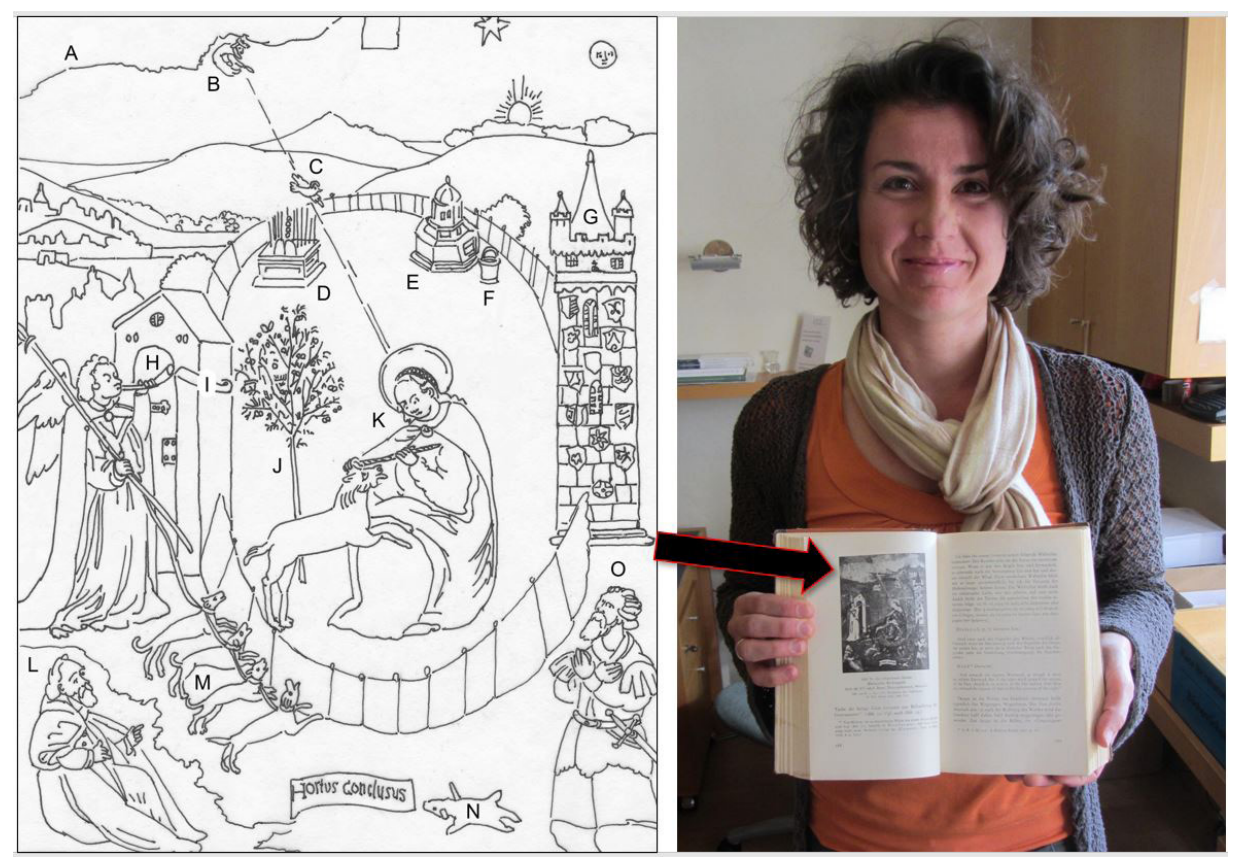

Fig. 10. Items in the Erfurt Hortus Conclusus (Symbols of Transformation, Plate VIII).

A. Aurora consurgens: 'morning rising' (Canticles 6:9)

B. No Latin label: God

C. No Latin label: The Holy Spirit

D. Virga a[a]ronis: Aaron's [budding] rod (Hebrews 9:4/Numbers 17:8)

E. Fons signatus: 'a fountain sealed' (Canticles 4:12)

F. Urna aurea: 'the golden urn' of manna (Hebrews 9:4)

G. Turris davidis: 'Tower of David' (Canticles 4:4)

H. Porta clausa: the closed gate (Ezekiel 41:2)

I. Ave Gratia Plena: 'Hail [Mary] Full of Grace' (Luke 1:28)

J. Quasi oliva speciosa: 'As a fair olive tree' (Ecclesiasticus 29:4)

K. Ecce ancilla Domini: 'Behold the Handmaid of the Lord' (Luke 1:38)

L. Isaias Propheta: 'Isaiah the Prophet' (Isaiah 7:14 \& Matthew 1:23)

M. Iustitia, Veritas, Miseracordia, and Pax: 'Justice, Truth, Mercy, and Peace'(Vulgate Psalm 84:11)

N. Vellus gideonis: 'Gideon's fleece' (Judges 6:36-40)

O. Gideon.

(Pictured right: Julia Budai, Librarian at the C.G. Jung Institute in Küsnacht, Switzerland, holding a 1952 edition of Symbole der Wandlung open to Abbildung 50 [Plate VIII]). 
In 'The Concept of the Collective Unconscious' Jung remarked that,

it is in the highest degree unlikely that his [Schwyzer's] vision had anything to do with the rare medieval representations of the Conception, even if through some incredibly improbable chance he had ever seen a copy of such a painting...He had never travelled. And there is no such picture in the public art gallery in Zürich, his native town' (Jung 1934:52 / CW 9.I:§109).

Despite Jung's being mistaken here (Schwyzer had traveled), his statement may be suggestive. It seems highly probably that Jung would have been aware of the fact that one of the most beautiful and celebrated Hortus Conclusus / Unicorn Hunt tapestries in the world is at the Landesmuseum Zürich and has been on permanent display there since it was acquired in 1896 (Fig. 11). ${ }^{82}$ A picture of this famous tapestry appears in Jung's Psychology and Alchemy (1968:442, fig. 245/CW 12:§521 = 1972:504, abb. 245/GW 12:§522).

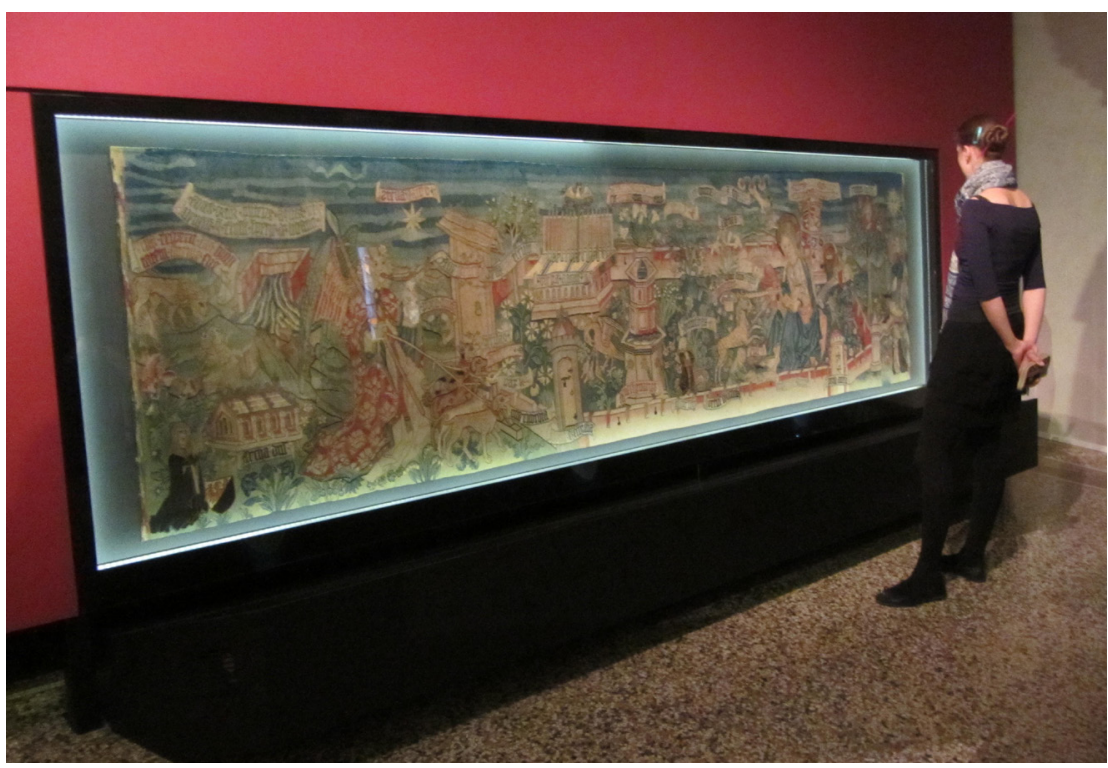

Fig. 11. Hortus Conclusus tapestry (1480), Swiss National Museum, Zürich, from the Kreuzkapelle in Lachen, Canton of Schwyz.

Schwyzer did not have his second breakdown and confinement until the Spring of 1897, after having worked as a clerk (commis) in Zürich for

\footnotetext{
${ }^{82}$ Andreas Hösli to the author 25 March 2014. For the details of the museums acquiring the item see Scwheizerisches Landesmuseum in Zürich 5: Jahresbericht 1896:78-80. This is not the only Hortus Conclusis image at the Landesmuseum (see, e.g., Wyss 1960:113-24).
} 
the 8 years previous. So it is quite possible he saw it too. Deirdre Bair even claims that Schwyzer was 'an employee of the Swiss Landesmuseum in Zürich' (Bair 2003:706, n.19 = 2007:994, n.19). ${ }^{83}$ In any case, when Jung stated that there was "no such picture in the public art gallery in Zürich, his native town', it should probably count for yet another piece of evidence to suggest that the Hortus Conclusus picture presented in Plate VIII was not the picture he had in mind when writing the accompanying text. It also raises the question of how involved Jung was at the stage of the production of Symbole in which the pictures were inserted and linked to particular statements in the text.

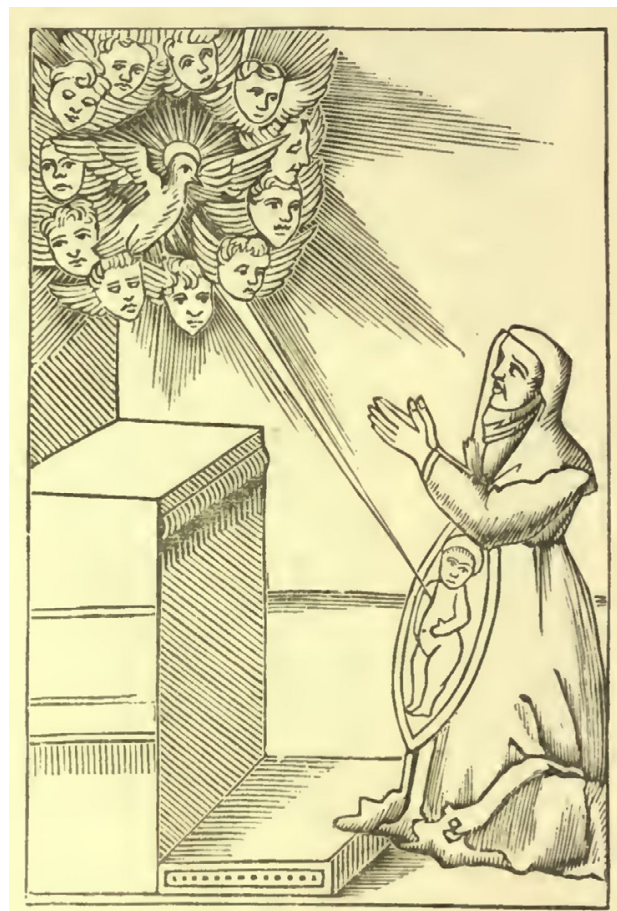

Figure 138.

Fig. 12. Picture from Thomas Inman's Ancient Pagan and Modern Christian Symbolism that Jung may have had in mind as a parallel to Schwyzer's solar-phallus 'vision'.
If the two plates given in Symbole did not really represent the actual theme or picture Jung originally had in mind, then what did? The obvious place to look for the answer is in the sources Jung was reading as part of the original preparation for Wandlungen. And when we do this a plausible answer presents itself in Figure 138 on page 92 of Thomas Inman's Ancient Pagan and Modern Christian Symbolism (Fig. 12). Even Inman's accompanying text for this figure is reminiscent of the language Jung used in describing the picture he had in mind: 'A circle of angels forming a sort of sun, having luminous rays outside, and a dove, the symbol of Venus, dart a spear (la pique) down upon the earth (la terra), or the virgin. This being received, fertility follows' (Inman 1875:92) ${ }^{84}$ 
There are a few points of doubt with this identification. The first is that Jung initially identified the artist as a German (Jung 1911:211, 1912a:94, 1916:108), and he retained this identification in Symbole (Jung $1952: 167,1956: 100-101 / C W 5: \S 150)$. But Inman's picture is from an Italian work by Alberto da Castello entitled Rosario della gloriosa Vergine Maria. Inman gives only an English title to the picture and says it was printed in Venice (1874:91). Then too it supposes that Jung followed Inman in the mistake of thinking the picture represented the Virgin Mary with the infant Jesus in her womb. Castello had actually identified it as a picture of Mary's mother Anna with the child Mary in her womb. ${ }^{85}$ Unlike the birth of Jesus, Mary's birth was not virginal, as we read in the promise to Mary's father Joachim in the Gospel of Pseudo-Matthew, the foundational text for the iconography of this subject in the Western Church: 'I am an angel of God...your wife...has conceived a daughter from your seed (ex semine tuo)' (Pseudo-Matthew 3:2; ET: Ehrman \& Pleše 2011:82-83). That Jung might have made this mistake is suggested by the fact that the same picture appears wrongly identified as the Virgin and child Jesus in Psychology and Alchemy (Jung 1968:179, fig. 87 / CW 12:244]). ${ }^{86}$ In short, the match is not perfect, the spear does not go up under Anna's dress, but it comes as close to doing so as anything this writer has seen.

\section{WHAT DID SCHWYZER SEE?}

Similar difficulties accompany Jung's 1911 reports of Honegger's discoveries regarding the 'hallucination' (Wahnidee) of Schwyzer. 'The patient sees in the sun an "upright tail" [Aufwärts-Schwanz] similar to an erect penis. When he moves his head back and forth, then, too, the sun's penis sways back and forth in a like manner, and out of that the wind arises' (Jung 1916:108-109, 1911:211, 1912a:94). As already noted, Jung derives the words 'upright tail' here from a passage in Honegger's 30 March 1910 Nuremberg paper.

It is interesting to note that in the context Honegger singled out Aufwärtsschwanz in the manuscript of his paper with quotation marks, as

than those of his source. He even adds la pique and la terra, giving the impression that they are in his source. They are not.

${ }^{85}$ Alberto da Castello, 1566, 38a: 'Maria vergine fu santificata nel ventre di santa Anna'.

86 There the source is identified in the List of Illustrations as coming from the Rosario della gloriosa Vergine Maria via Inman, but clearly the original book was not consulted. 
if wanting to preserve Schwyzer's precise wording at that point, raising once more the question whether Jung had suggested beforehand that he try to coax Schwyzer into redescribing his 1906 Solar-Phallus 'vision'? However, Honegger does not in any way suggest in his paper that Schwyzer equated the Aufwärtsschwanz with a penis. That was Jung's interpretation of what it meant, not Honegger's and not Schwyzer's on that particular occasion. Consistent with this, Jung does not actually say in the text that the patient saw an erect penis, only that he saw an, upright tail 'similar to' an erect penis. In the German he speaks of a 'so-called upright tail' (einen sogenannten "Aufwärts-Schwanz" [d.h. soviel wie erigierten Penis]).

Since Schwyzer had already identified the tail coming off the sun as a phallus in 1906 we may wonder what additional element Dieterich's Mithrasliturgie brought to the table when Jung read it in the summer of 1910. As he says in his earliest account: 'Honegger discovered the following hallucination... This strange hallucination remained unintelligible to us for a long time until $I$ became acquainted with the Mithraic liturgy' (Jung 1916:108-109 =1991:95-96 / CW Supp. B:§173, italics mine). Given his earlier experience with Schwyzer, Jung certainly already had some idea that Honegger's 'upright tail' might also have underlying phallic associations, even though, by his own admission, everything had not as yet fallen into place for him until he read the Mithrasliturgie. ${ }^{87}$ Interestingly the only really new thing the Mithrasliturgie seems to offer in terms of a parallel to Schwyzer's Solar-Phallus 'vision' is a connection between the aulos (which Jung took to be a penis) and the origin of the wind.

We have already mentioned a very significant lacuna in Jung's published statements on the Schwyzer case, namely, the fact that Schwyzer's had shot himself in the head, where the bullet presumably remained for the rest of his life. The injury appears to have resulted in

\footnotetext{
${ }^{87}$ Jung was apparently eager to advance his protégé's career by giving him credit for initially reporting Schwyzer's 'hallucination' of an Aufwärtsschwanz rising from the sun. This as we have seen was not entirely true. Jung also took pains to speak of the matter in a way that echoed the language of Honegger's paper. Later, however, in the major revision of Wandlungen that became Symbole der Wandlung, Jung credits himself with the discovery by replacing 'Honegger...entdeckt' with 'Ich habe... beobachtet'. He also replaces the allusion to Honegger's paper about the patient's seeing 'einen sogenannten "Aufwärts-Schwanz" [d.h. soviel wie erigierten Penis]' with the simpler 'ein membrum erectum'. Jung entered these corrections in his own hand into a copy of the 1938 third edition of Wandlungen (1938a:94). Thanks to Sonu Shamdasani for sharing crucial pages from this book containing Jung's corrections with me and for verifying Jung's handwriting. The book itself is currently housed in the Hochschularchiv der ETH Zürich, register number Hs 1301:1.
} 
a number of baneful physical consequences. ${ }^{88}$ Early on these included confused speech (mixing French, English, and German words), ${ }^{89}$ loss of memory and any real sense of chronology, ${ }^{90}$ the loss of the ability to stick out his tongue, ${ }^{91}$ rapid weight gain, ${ }^{92}$ twitching on his right side, ${ }^{93}$ weakness in his right hand (Casebook 134: Males 1888, \# 38:[3]), ${ }^{44}$ the onset of 'weakmindedness', (10 October 1888, Casebook 134: Males 1888 , \# 38:[4]) and epileptic type seizures accompanied by foaming at the mouth (18 May 1888, Casebook 134: Males 1888, \# 38:[3]). The original head wound was followed by others. It is reported that during one of his seizures Schwyzer fell, hitting his head on the floor causing the bruising of his left occipital region (ibid.). Schwyzer suffered at least two other self-inflicted head injuries when trying to kill himself by bashing his head against a door in one case and a wall in another (21 April 1888, Casebook 134: Males 1888, \# 38:[3]). ${ }^{95}$

But the most conspicuous and lasting effect of Schwyzer's suicide attempt was the damage done to his left eye. This was discussed at some length in the Guy's and Bethlem records, and mentioned as well in the Swiss records accessed by Honegger. The most complete description comes from the Bethlem record on the occasion of the examination of Schwyzer on or soon after his arrival there on 14 April 1888:

$\mathrm{R}^{\text {[igh]t }}$ Eye is normal. $\mathrm{L}^{\text {[ef]t }}$ Eye Ptosis [drooping upper eyelid] + external Strabismus [outward non-alignment]. He has complete

\footnotetext{
${ }^{88}$ Unfortunately we know nothing of Schwyzer's physical or mental condition prior to his attempted suicide beyond the fact that he seems to have been delusional after losing his job.

8925 March 1888 ('Abstract of Report on Emile Schweizer' [1888]:2).

90 When he arrived at Bethlem he told them he had been at Guy's hospital for 6 months, when he was actually only been there since 12 February, scarcely more than two months (Casebook 134: Males 1888, \# 38:[3]).

9121 April 1888 (Casebook 134: Males 1888, \# 38:[3]). This may be a consequence of an additional self-inflicted injury to his head (see below).

${ }^{92}$ When Schwyzer arrived at Bethlem on 14 April 1888, he was described as a 'thin, rather delicate' man, but by 10 October of that same year he had become 'very fat' (Casebook 134: Males 1888, \# 38:[1, 3-4]).

9314 February 1888 ('Abstract of Report on Emile Schweizer’ [1888]:1).

${ }^{94}$ But this may have been partly due to his being left-handed, which is suggested by his shooting himself in the left side of his head.

95 Also in the Spring of 1897 at Mönchhof bei Kilchberg (Hs 1068:18, 3). In the latter case at least he was apparently attempting suicide.
} 
paralysis of all his ocular both intra and extra ocular muscles with the exception of the External Rectus. $\mathrm{L}^{\text {[ef]t }}$ Pupil is dilated + does not react either to light or accommodation. Apparently he has no diplopia [double vision]. When made to follow an object with his $\mathrm{R}^{\text {[igh]t }}$ Eye he follows till the object come[s] opposite the visual axis of his $\mathrm{L}^{\text {[ef]t }}$ Eye + then he lets his $\mathrm{R}^{\text {[igh]t }}$ Eye turn out + fixes the object with his Left. He says he does not see double. He can count fingers with his Left Eye + he says he can see quite well with it...Both disks very pale. Field of vision for white is normal in $\mathrm{R}^{[\mathrm{igh}] \mathrm{t}}$ Eye a little contracted in $\mathrm{L}^{\text {[ef]t }}$. Field for colours is much contracted in both eyes. (Casebook 134: Males 1888, \# $38:[3])$.

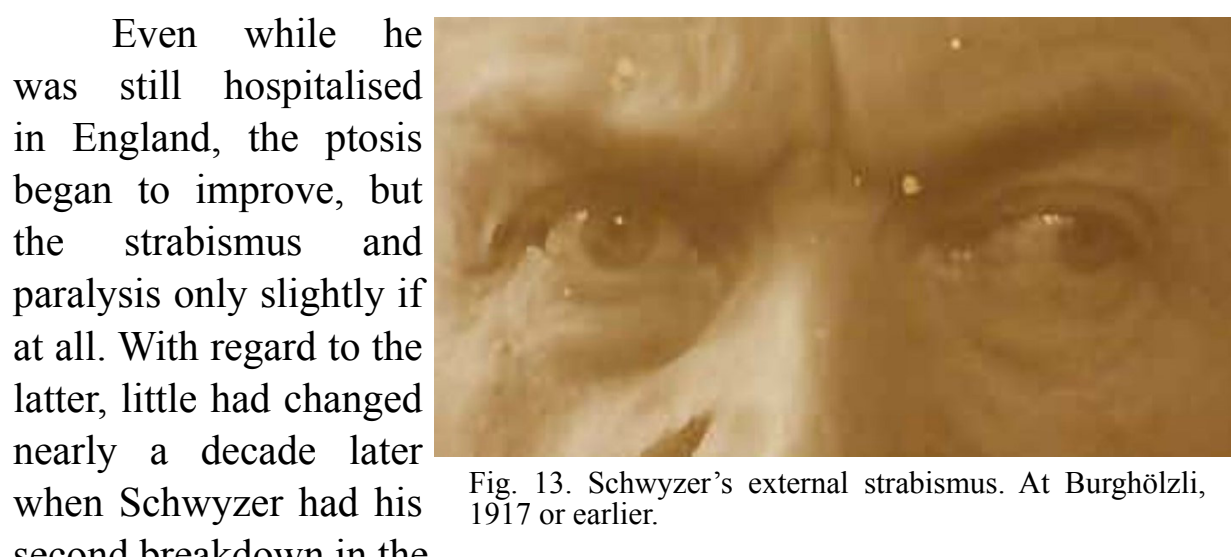
second breakdown in the Spring of 1897, when we read of paralysis of the right [sic] side of the face, the right eye having a 'neuropathic expression' and a fixed gaze, a conspicuous external strabismus with the left eye lying fixed in its outer corner, and the scar from the gunshot wound in the left temple area. ${ }^{96}$ Finally, Honegger's 1910 Nuremberg paper also makes it clear that at that time Schwyzer still had the external strabismus ("nach aussen schielenden') (Hs 1068:17, Ms 11/Ts 9). According to Honegger, Schwyzer described his fixed left eye as, 'cosmic' and 'the sun' (Fig. 13).

Though trauma to the head, brain, and eyes of the sort Schwyzer suffered, occasionally result in hallucinations, this does not seem to be what was occurring in his case.${ }^{97}$ Indeed it is a question whether, strictly

\footnotetext{
${ }^{96}$ Hs 1068:18,[8]: 'eine Fazialisparese rechts. Das linke Auge steht unbeweglich im aüßeren Augenwinkel, schielt nach links aussen. Schussnarbe in der linken Schläfengegend. Das rechte Auge zeigt einen neuropathischen Ausdruck, de[r?] Blick ist starr'.

97 Thanks to Dr. Rob Cheeley of Project Grace in Yunnan, China, for help with questions relating to head injuries and hallucinations.
} 
speaking, he ever had hallucinations in the sense of seeing things that were not there. To be sure he was delusional, and in this case he seems to have been exploiting his eye injury to create visual phenomena for himself to which he would then assigned delusional significance. He did this by a combination of squinting, of closing his eyes half way, of waggling his head, of alternately closing and opening his eyes. In Honegger's paper such actions are referred to as Schwyzer's 'sun experiments' (Sonnenexperimente) (Hs 1068:17, Ms 11/Ts 9).

In the Bethlem account we saw that when Schwyzer fixed an object with his left eye his right eye would 'turn out' (Casebook 134: Males 1888, \# 38:[3]). From Honegger's paper we learn that Schwyzer appears to have exploited this capacity as part and parcel of making his 'sun experiments'. If, while looking at the sun, he alternately closed his right and left eyes it would seem to make the sun jump around. ${ }^{98}$ Taking advantage of the partial disconnect between his two eyes, Schwyzer could also make the sun seem to elongate and even pull apart. Honegger described these abilities as 'eine feine Kompensation für die kosmetische Entstellung', 'a fine compensation for the cosmetic disfigurement' (Hs 1068:17, Ms 11/Ts 9).

\section{THE AUFW ÄRTSSCHWANZ, A RAY OF LIGHT (LICHTSTRAHL) NOT A PHALLUS}

Like several other words Schwanz can serve as a vulgarism to refer to a penis (Küpper 1982-1984:8,2583), but that is not what Schwyzer had

\footnotetext{
${ }^{98}$ Here is the relevant passage from Honegger's paper for this and what follows: Der Herr gefällt sich nun auch im Genusse seiner Allmacht: Er macht in der freien Zeit Sonnenexperimente: Er bringt die Sonne zum Hüpfen, indem er d. r. Auge schliesst, und sie mit dem linken, sonst nach aussen schielenden fixiert. Die Sonne hat dann einen scheinbaren Ruck nach links gemacht. Wenn er d. schielende schliesst, so bleibt der Effekt natürlich aus. Er bezeichnet daher sein linkes Auge als das kosmische, als die Sonne, eine feine Kompensation für die kosmetische Entstellung. Er pflegt auch gerne die Sonne mit halbgeschlossenen Augen anzublicken und sie dadurch zum Tanzen zu bringen, ein Spiel, das auch mit gewöhnl. Lichtern sehr genussreich ist. Besonders schön ist es, die Sonne durch starkes Zukneifen der Augen in die Länge zu ziehen, auseinanderzuziehen, ihr einen 'Aufwärtsschwanz' aufzusetzen. Wenn er dabei den Kopf im Takt einer Melodie hin u. her wiegt, so wird dieser Aufwärtsschwanz (der Reflex) wie eine Fahne hin- u. her geschwenkt und dadurch entsteht dann der Wind. Hier wieder die Vorstellung von materiellen Lichtstrahlen. [...] Ganz wie d. Kinder glaubt er, dass ihm die Wolken und der Mond nachlaufen wohin er geht. Geht er den See entlang, so weist der Reflex des Mondes immer auf ihn, so dass die hinter ihm Gehenden sehen müssen: Davorne [sic, Ts reads: Da vorne] geht der Herr. Das ist das Leiden der Verbindg. des Herrn mit den Gestirnen [...]' (Hs 1068:17, Ms 11/Ts 9). My bolding.
} 
in mind when he spoke to Honegger in 1910. He did not suggest that the Aufwärtsschwanz referred to was a penis, but a 'reflection' (der Reflex), a tail of light he was able to cause to rise from the sun by squinting at it. When Schwyzer combined this action with moving his head back and forth to music, the tail of light would move back and forth too, not like a penis, as Jung suggested, but like a 'flag' (Fahne).

What Honegger was reporting, then, was not a hallucination at all, but a universally familiar visual phenomenon of the sort Hermann Hesse described in his 1927 short story Dream Journeys, when he spoke of 'a flickering round of dancing lights such as anyone sees when squinting at the sun' (Hesse 1972.286-287). ${ }^{99}$ It is a phenomemon especially easy to recreate by squinting at street lights at night or at the table lamp on your desk.

In the same context Honegger reports that Schwyzer also thought that when he walked along the lake and the reflection of the moon (der Reflex des Mondes) on the water always pointed to him, it was to let other people know that he was the Lord. This is again a delusional interpretation of a natural phenomenon that everyone has experienced of the kind described very well in Italo Calvino's description of Mr. Palomar's evening swim:

As the sun sinks toward sunset, the incandescent-white reflection acquires gold and copper tones. And wherever Mr. Palomar moves, he remains the vertex of that sharp, gilded triangle; the sword follows him, pointing him out like the hand of a watch whose pivot is the sun. 'This is a special homage the sun pays to me personally,' Mr. Palomar is tempted to think, or, rather, the egocentric, megalomaniac ego that dwells in him is tempted to think (Calvino 1985:13-14).

What Mr. Polomar was 'tempted to think' Schwyzer really did think. He also really thought that the visual phenomena he made himself see in the course of his sun experiments were actually happening in the external world. Since he viewed himself as the creator of all things, Schwyzer regularly interpreted external events as being directly caused by him. He attributed the devastating 28 December 1908 Messina earthquake to his becoming angry at another patient for contaminating his dishwater. He also thought that the 8 May 1902 eruption of Mount Pelée on the island of Martinique was caused by his jumping from a first-floor window to

99 '...einen flimmernden Reigen bewegter Lichter, wie jeder ihn beim Blinzeln gegen die Sonne sieht' (Hesse 2001:8,393). 
retrieve a wash rag. In the process the sun bounced, hit the top of the volcano, and caused the eruption (Hs 1068:17, Ms 11/Ts 9).

As we see from the dates of the two events, Schwyzer's God delusion with its imagined implications for the external world was long standing. In fact, it was already present at the beginning of his second breakdown and institutionalisation in 1897 (Hs 1068:18 [8]: 'Er sei der persönliche Gott.'). And the conviction that his actions affected the external world was already present in his 1888 Guy's hospital report, where he expressed his belief that the 'accidents received into the ward were caused by his faults' (Casebook Males 1888 (CB/134), \# 38:[1]).

The Sonnenexperimente he produced by squinting at the sun that Jung observed in 1906 and Honegger in 1910 also went back to at least 1897. It is reported that when he was in Mönchhof in the Spring of 1897 Schwyzer was making weather (Hs 1068:18 [8] 'Im Mönchhof habe er Wetter gemacht.'). ${ }^{100}$ And then by February 1898 in Münsterlingen he was already commenting on how he was able to make the sun strangely jump around in the sky by squinting at it (Hs 1068:18 [10]: 'Er sieht die Sonne blinzelnd an sind erklärt, sie mache so eigentümlich lustige Rücke am Himmel.'). On yet another occasion Schwyzer said he made weather to keep someone away from him (Hs 1068:18,3: 'Es sei ihr gesagt worden, er erzeuge Winde, so dass sie sich ihm nicht nähern könne.').

Honegger concludes from the fact that Schwyzer waggled his head to move the Aufwärtsschwanz back and forth to make wind, that he must have been viewing it as in some sense substantial, or material, in itself. And in the course of explaining this, Honegger removes any remaining doubt that he regarded the upright tails Schwyzer was raising from the sun by squinting at it in 1910 as materialised rays of light (materiellen Lichtstrahlen) not phalli. ${ }^{101}$ Schwyzer's idea, says Honegger, corresponded to "infantile notions of the sunbeam" (infantilen Vorstellungen vom Sonnenstrahl)", which he illustrates with a reference to Wilhelm Busch's children's book Der heilige Antonius von Padua (1872) where Saint Anthony is said to hang his cap on a warm sunbeam (einen warmen Sonnenstrahl) (Fig 14). ${ }^{102}$

\footnotetext{
${ }^{100}$ In this case by making snow come through the wall.

${ }^{101} \mathrm{He}$ also referred to them as material rays of light in a passage he crossed out at the same place (Hs 1068:17, Ms 11).

102 'Flugs nimmt Antonia seine Haube // Und Hängt sie, wie an einen Pfahl //An einen warmen Sonnenstrahl' (Busch 1972:41).
} 


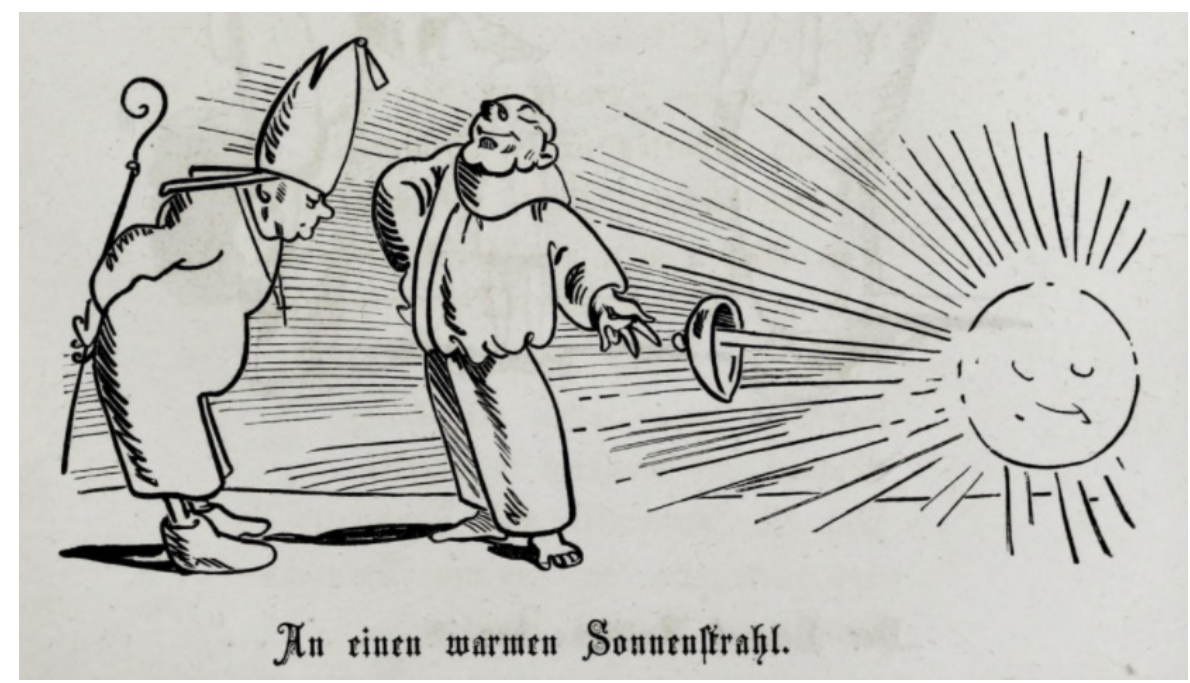

Fig. 14. Illustration of St. Anthony hanging his cap on a sunbeam in Wilhelm Busch's children's book Der heilige Antonius von Padua (1872), cited by Honegger in his 30 March 1910 paper on the Schwyzer case at the Second Psychoanalytic Congress in Nuremberg.

Honegger also mentions as another parallel, children's stories where the sun is presented as a woman with golden hair (=rays of the light) that could be plucked. ${ }^{103}$ Both illustrations were chosen to provide additional examples of material rays of light (materiellen Lichtstrahlen) in order to tie what Schwyzer was seeing with common stock motifs of myths and stories. ${ }^{104}$

We can well imagine that Jung might not have been satisfied with these parallels, coming as they did from childrens stories that everyone, including Schwyzer, might have been familiar with. What he needed were parallels that Schwyzer could not possibly have known about. These he felt sure he had found in the Mithrasliturgy and in Medieval pictures showing a tube coming down from heaven and under the Virgin's robe to impregnate her.

From Jung's descriptions of the 1906 incident, it is clear that Schwyzer was doing the same sort of thing then as he was in 1898 in Münsterlingen and in 1910 when talking to Honegger. He was engaging in his 'sun experiments'. While 'wagging his head and blinking into the sun', Schwyzer had explained to Jung that 'when I move my head to and fro, it [the sun's penis] moves too' (Jung 1934:50-51/ CW 9.I:105). Schwyzer realised that if other people did the same thing he was doing, they could generate the same visual phenomenon themselves.

\footnotetext{
${ }^{103}$ The identification of the plucked hair as Lichtstrahlen also appears in Hs 1068:17, Ms 8/Ts 7 .

${ }^{104}$ Honegger's third example comes from Daniel Paul Schreber's description of 'the rays of a whole world [Strahlen einer ganzen Welt]—-somehow mechanically fastened at their starting points', that seemed to saw his head in pieces when he was suffering from mental illness (Schreber 1988:136 = 1903:155 [German ed.]).
} 
According to Jung, Schwyzer 'invited me to blink into the sun like he did and waggle my head' (1934:52 / CW 107:§52), 'said I must look at the sun with eyes half shut, and then I could see the sun's phallus' (Jung 1931:150/CW 8:\$317). And he told Jung, 'you must move your head, too, like this' (Jung \& Freeman 1959:434). Jung attempted it but for some reason was unsuccessful (Jung 1935:41/CW18:§85). The fact that Jung failed actually surprised Schwyzer as it might well surprise us also (Jung 1934:50-51/ CW 9.I: 1105 ). The only difference between the accounts of Jung and Honegger is that in 1906 Schwyzer identified the light tail he saw on the sun as a phallus whereas in 1910 he did not.

For years Schwyzer had been identifying himself with the sun. In March 1898 he was reported as saying that he himself was the sun (Pat. sagt, er sei die Sonne), that the sun had been in his mother womb before his birth, and that if he had died before birth all would be darkness (Hs 1068:18, [10]). In the same context he claimed that he himself had set the course of the sun, which had previously wandered about randomly. In Honegger's 1910 paper Schwyzer claimed that before he was born there was no sun, only a yellow sky. It only took its circular shape after his birth (Hs 1068:17, Ms 4/Ts 3).

As noted earlier, Schwyzer interpreted the whole universe as being formed from his own seed. As such it is scarcely incredible that he might have occasionally interpreted the Aufwärtsschwanz, the light ray he liked to produce by squinting at the sun, as a solar phallus, that is to say, as in some sense his own phallus. But he did not interpret it that way when speaking with Honegger, nor in any other place known to this author except the 1906 incident. ${ }^{105}$ Nor can we say that Jung took undue credit for Honegger's research. The two men interpreted the Aufwärtsschwanz in two distinctly different ways, Honegger as a material light beam and Jung, informed by his earlier experience, as a solar phallus paralleled in the Mithrasliturgie.

In any case, using words like 'hallucination' (Wahnidee) and 'vision' to describe what Schwyzer called a 'solar phallus' in 1906 and an 'upright tail' in 1910 does not really do justice to what was actually occurring. There was nothing at all unusual in the manner in which Schwyzer made himself see the tail (anyone, or most anyone, can do it any time they like). The only thing that made Schwyzer's experience different was that he seems to have actually believed that his sun experiments affected external

\footnotetext{
${ }^{105}$ In Honegger's paper Schwyzer described the sun as consisting of the moon and the stars coming together. (Hs 1068:17, Ms 8/Ts 7). In the context he likens the combination to coitus, apparently having in mind an image of an ovum (the moon) surrounded by sperm such as he might have seen, for example, in Haeckel 1874:137, fig. 12.
} 
reality. That was certainly delusional, but it did not really amount to a vision or hallucination.

\section{CONCLUSION}

On 12 February 1888 a despondent and delusional Emil Schwyzer, later to be nick-named 'the Solar-Phallus Man', pressed a small pistol against his left temple and pulled the trigger. He had recently been fired from his position at a bank. He was 25 years old at the time and living at 28 Finsbury Square, London. After shooting himself Schwyzer was rushed to Guy's hospital. He survived but the bullet had caused significant damage to his head, including paralyzing his left eye so that it lay fixed in its socket in an outward-looking position (external Strabismus). When asked to follow an object with his right eye he would do so until it reached the visual axis of his left, at which point the left eye would take over and his right eye would fall back. Eventually Schwyzer came to believe he was the creator of all things, and that he could actually make the sun do things in the sky by looking at it in various ways, aided more or less by this disconnect between his two eyes. By alternately opening and closing his right and left eyes, he could make the sun seem to jump around in the sky. By squinting at it hard, he could cause it to elongate and even pull apart. Jung's assistant J.J. Honegger described the enjoyment Schwyzer got out of making these 'sun experiments' (Sonnenexperimente) as a 'compensation for the cosmetic disfigurement'. (Hs 1068:17, Ms 11/Ts 9) Another thing Schwyzer would do along these lines was to make an 'upright tail' (Aufwärtsschwanz) of light rise from the sun by squinting at it. This was a visual phenomenon that most people with normal vision can make themselves see as well by squinting at, say, a table lamp or streetlight, but with one difference. Schwyzer actually believed that the visual phenomenon he created by doing this was real and substantial so that when he moved his head back and forth and the tail of light seemed to move with it the air was stirred up and wind was created.

Schwyzer was already making weather and causing the sun to jump around in the sky as early as 1897/1898, well before coming into contact with either Jung or Honneger (Hs 1068:18 [8], [10]). ${ }^{106}$ In 1906 Jung encountered

\footnotetext{
${ }^{106}$ Could it be Schwyzer Eugen Bleuler was describing in the following passage?: 'A hebephrenic made fun of himself because he, the Lord, walked between two doctors and yet did not know how to get out of the hospital. While he was a patient in another hospital, he used to make the weather, right after tea time. Here in this institution, nothing seemed to happen after coffee-time. A "King of the Whole World" himself asked the question "whether all this did not sound rather fantastic"'(Bleuler 1950:127-
} 
Schwyzer squinting at the sun and waggling his head to make wind with the light tail. On that occasion Schwyzer described the tail of light as the sun's penis. In early 1910 Jung's assistant J.J. Honegger observed Schwyzer doing the same thing but describing the resultant upright tail (Aufwärtsschwanz) not as a solar phallus but as a reflexion (Reflex), a ray of light (Lichtstrahl), which made wind when it moved back and forth like a flag (Fahne).

Schyzwer's Aufwärtsschwanz and other 'sun experiments' represented a relatively minor point in the 30 March 1910 paper Honegger gave at the Second Psychoanalytic Congress in Nuremberg. The main focus of that paper was a presentation of Schwyzer's concept of the cosmos he believed he had created from his own seed, the central feature of which was a Ptolemaic flat earth.

In Wandlungen und Symbole der Libido (1912 [1911]), Jung made reference to Honegger's mention of Schwyzer's Aufwärtsschwanz but gave it a phallic interpretation. Between Honegger's paper and Wandlungen Jung had discovered what he believed to be two significant parallels that provided the key to understanding what Schwyzer was seeing in both 1906 and 1910. The first parallel was an obscure passage in an ancient work known as the Mithrasliturgie that seemed to feature a pipe (Röhre) hanging from the sun which was described as the 'origin of the ministering wind'. The second was a theme in Medieval art that showed a 'tube' (Röhre) or 'pipe' (Schlauch) ${ }^{107}$ coming down from heaven and passing beneath the robe of Mary', into which 'flies the Holy Ghost in the form of a dove for the impregnation of the Mother of God' (Jung 1912a:94, 1952:11 (CW 5.150), 1991:95 (CW Supp. Vol. B:§172)). Jung insisted that Schwyzer could not have known about the Mithrasliturgie passage nor the theme in Medieval art because the former had not been published until four years after Schwyzer had his 1906 solar-phallus 'vision' (not correct), and because Schwyzer never traveled and no example of the type of picture he was describing was to be found in Zürich (also not correct and...complicated). Jung regularly featured the Schwyzer case as an example of 'the fantasies or delusions of his patients ...paralleled in mythological material of which they knew nothing' (Bennet 1985:69). ${ }^{108}$ Following are the broad conclusions of this article:

1. Jung did not get his claim that Schwyzer saw a solar phallus from Honegger's 1910 paper, since Honegger made no such claim there.

\footnotetext{
128=1911:104 [German ed.]).

107 'Pipe' was changed to 'hose-pipe' to translate Schlauch in Jung 1956:101/CW 5.150.

${ }^{108}$ Not referring specifically to the Schwyzer case, although it may have been the case Jung had in mind.
} 
Rather he reinterpreted the 'upright tail' (Aufwärtsschwanz) mentioned by Honegger as a solar phallus based on his own reading of Albrecht Dieterich's edition of the Mithrasliturgie a few months later. Once one sees the bigger picture this is clear even from the language Jung uses in his first mention of the matter in Wandlungen itself.

2. Jung's use of terms like 'vision' and 'hallucination' to describe what Schwyzer saw is not apt. Schwyzer's Aufwärtsschwanz was not a hallucinatory event but one of a series of self-generated 'sun experiments' (Sonnenexperimente) that he had engaged in from time to time over a long period as a way of amusing himself. The delusional element was that he imagined that what he made himself see was actually affecting the external world.

3. The Mithrasliturgie cannot be appealed to as a parallel to Schwyzer's 'vision' of a solar phallus because there is no reference in that work to a solar phallus. Jung was misled by both Dieterich's translation and his own copy of Wilhelm Pape's Griechisch-deutsches Handwörterbuch (1849) into accepting the translation of the Greek word aulos in the Mithrasliturgie as a Röhre ('pipe'), by which he understood a single pipe hanging from the sun, which he took to be an indirect reference to a penis. However, it was not that. The reference rather was to the sun's playing an aulos, the familiar double-piped instrument depicted everywhere in Roman and Greek art, and especially on Greek vases. The only real parallel between what Schwyzer saw and what the Mithrasliturgie describes is that in both cases wind was produced. In the former case by the air's being stirred up by the back-and-forth movement of the Aufwärtsschwanz and in the latter by the sun's blowing air through his double-piped musical instrument.

4. The obscure Medieval art theme of a tube coming down from heaven and up under the Virgin Mary's cloak to impregnate her also falls short as a significant parallel to what Schwyzer saw. The simple reason is that no such obscure Medieval theme apparently exists, or even supposing it did, Jung never revealed where. Neither of the two images contributed by Jolande Jacobi 40 years after the fact to illustrate Jung's claim about the theme in Symbole der Wandlung/Symbols of Transformation have anything to do with what Jung described. We argue however that Jung actually did have a particular image in mind. He had seen it in Thomas Inman's Ancient Pagan and Modern Christian Symbolism (1874), one of the first volumes he read when his passion for the study of mythology began in the fall of 1909. However, Inman mistakenly imagined that the picture showed Jesus in his mother Mary's womb, when it actually depicted Mary in her mother Anna's womb. Jung reproduces Inman's picture along with his confusion 
about who the figures represent in Psychology of Alchemy.

5. Although Jung does not name the patient in a letter he wrote to Freud on 4 June 1907, there can be no doubt that he was describing Schwyzer. From the letter it is clear that at the time Jung was aware of a number of relevant details about the case that he either never mentions in his published accounts (e.g., that Schwyzer had shot himself in the head), or directly contradicts (e.g., that Schwyzer had in fact traveled). In June/July 1910 Jung told Adolf Meyer about analyzing Schwyzer three years previous (i.e., 1907) but without significant results. Once Jung and Honegger had begun actively seeking proof of connections between the symbols of myth and the delusions of mental patients expressing inherited ideas, Jung's interest in Schwyzer appears to have been rekindled. As noted earlier, according to Honegger's 1910 paper, Schwyzer did not interpret that upright tail as a phallus but as a ray of light (Lichtstrahl). It was Jung who, through his later reading of the Mithrasliturgie and perhaps under the influence of his recollection of the 1906 solar-phallus incident as well, took the step of interpreting what Honegger reported as a phallus.

The idea of a lens-shaped flat earth, which was the central focus of Honegger's paper, may have come to Schwyzer via contact with the very active flat-earth movement going on in England while he was there. However, being convinced instead that the notion came to Schwyzer from the realm of inherited ideas, Honegger and Jung did not explore that possibility.

6. It is not clear whether Jung recommended Schwyzer as the subject of Honegger's two-month study based on his own recollection of the 1906 solar-phallus incident, or was simply reminded of the earlier incident by Honegger's reference to Schwyzer seeing an Aufwärtsschwanz. What is clear is that despite his renewed interest in the case, Jung never seems to have gone back and fully refreshed his memory about the other details of Schwyzer's patient history. Why Jung never did so might be partially explained by potential difficulties connected with accessing the patient himself. Such may at least be suggested by the attendant chronology of events. Jung had resigned from his position at Burghölzli several months before Honegger began his research on Schwyzer as a volunteer there at the beginning of 1910. It appears that at the time some hostility existed at the clinic toward Jung and his methods and that this may even have caused Honegger to be asked to leave earlier than he had intended after being too vocal in his defense of Jung (F/J 186J:308 [17 April 1910]).

When Honegger committed suicide the following year, Jung scrambled to salvage as much of his research as possible (F/J 252J:416 [19 
April 1911]). Honegger's research on Schwyzer was among the materials Jung managed to recover. However, it remains unclear whether Jung ever actually reviewed their contents. In any case, Jung gave Honegger's papers to his assistant Carl Alfred Meier in the early 1930s 'suggesting he might do something with them' (William McGuire to K.R. Eissler, 1 Mar 1976:2, William McGuire Papers, Bx 43, Fd 5; Manuscript Division, Library of Congress, Washington, DC). Meier was working at Burghölzli in those years, knew Schwyzer and, being on site, had ongoing access to him. But ultimately Meier reported failure, noting that he 'never succeeded in finding out the function of the solar phallus in his [Schwyzer's] hallucination system' (Meier 1995:78). ${ }^{109}$ It has been our purpose in the present article to take a fresh look at this case that so intrigued Jung throughout his life in order to see whether we might be able to move our understanding of it a few steps forward.

\section{ACKNOWLEDGEMENTS}

This article is dedicated to the late Tom Cunningham (d. 20 Jan 2016), former monk, professor of philosophy, specialist in Arab interpreters of Aristotle, enthusiastic helper in the earliest stages of this project, friend. I am especially grateful to the following people for generous help of various kinds that has greatly enhanced the present work: Sonu Shamdasani (University College London and the Philemon Foundation), Thomas Fischer (Stiftung der Werke von C.G. Jung), Colin Gale (Bethlem Museum of the Mind), David Luck (Bethlem Royal Hopital), Verena Rothenbühler (Staatsarchiv of the Canton of Zürich), Claudia Briellmann (Hochschularchiv, ETH Zürich), and Nicola Behrens (Stadtarchiv Zürich). Special thanks to my daughter and son-in-law, Sarah and Andreas Löcker, who always stood ready to help me sort out the German, and to Sarah especially for her inestimable help during a research trip to Zürich, making quick summary translations of manuscripts, chasing down needed

\footnotetext{
${ }^{109}$ A curious feature of the Honegger papers is that some files are permeated by a strong smell of pipe tobacco and/or are marked with fingerprints, in some cases unusually large round thumb prints, indicating perhaps the level of interest taken in them. Others are not. So, for example, Schwyzer's Patient History (Hs 1068:18) smells of tobacco and has fingerprints, while the manuscript of Honegger's Nuremberg paper (Hs 1068:17) hardly does at all. As to who it was showing the interest (Jung and/or Meier) remains a mystery, at least to this author, since both men smoked cigars and pipes. Sonu Shamdasani remarks: 'I've looked over a lot of Jung's manuscripts and not noticed this [the smell of pipe smoke], which would lead me to suppose that it was Meier's' (Shamdasani to author, 10 Nov 2021)
} 
materials, and helping with photography. I would also like to thank my research assistant Isaiah Johnson for his help during a visit to Bethlem Royal Hospital. In addition to these I also want to thank the many other staff members from the following archives and institutions who provided valuable help (some of whom are named in footnotes above):

Alan Mason Chesney Medical Archives, Baltimore, MD.

Bethlem Royal Hospital, London, Archives and Museum of the Mind Archives.

Sigmund Freud Museum, Vienna

Hochschularchiv der ETH, Zürich

Jung Family Archives, Küsnacht

Landesmuseum, Zürich

Manuscript Division, Library of Congress, Washington D.C.

Staatsarchiv des Kantons, Zürich

Stadtarchiv, Zürich

\section{BIBLIOGRAPHY}

Alberto da Castello, 1566. Rosario della gloriosa Vergine Maria. [Venice: Giovanni Varisco].

Anonymous. 1856. 'Review of John Wilson's The Lost Solar System of the Ancients Discovered.' The Athenaeum (Aug 2):952-953.

Bair, Deirdre. 2003. Jung: A Biography. Boston: Little, Brown. Btb.

Bastian, A. 1868. 'Der Baum in vergleichender Ethnologie.' Zeitschrift für Völkerpsychologie und Sprachwissenschaft 5:287-316.

Beker-Lamers, Cornelie. 2003. 'Maria mit dem Einhorn: Erfurts Keinod der Kunstgeschichte.' Passau: Kunstverlag Peda (Brochure). 
Bennet, E.A. 1985. Meetings with Jung: Conversations Recorded During the Years 1946-1961. Zürich: Daimon.

Betz, Hans Dieter (ed.). 1986. The Greek Magical Papyri in Translation: Including the Demotic Spells. Chicago \& London: University of Chicago Press.

- 2005. The 'Mithras Liturgy': Text, Translation, and Commentary. Tübingen: Mohr Siebeck.

Bleuler, Eugen. 1911. Dementia Praecox oder die Gruppe der Schizophrenien. Leipzig und Wien: Franz Deuticke. 1950 [1911]. Dementia Praecox: Or the Group of Schizophrenias. Tr. Joseph Zinkin; fwd. Nolan D.C. Lewis; New York: International Universities Press.

—. 1916. Lehrbuch der Psychiatrie. Berlin: Julius Springer.

-1924. Text-Book of Psychiatry. Tr. A.A. Brill. New York: Macmillan.

Bryant, Jacob. 1773. A New System, or, An Analysis of Ancient Mythology I. London: P. Elmsly.

Brown, Rachel Fulton. 2018. Mary and the Art of Prayer: The Hours of the Virgin in Medieval Christian Life and Thought. New York: Columbia University Press.

Brush, Edward N. 1905. 'Notes of a Visit to Some Foreign Hospitals for the Insane-Mainly in Germany.' The American Journal of Insanity 61(4) April:639-670.

Busch, Wilhelm. 1872. Der heilige Antonius von Padua. Strassburg: Moritz Schauenburg.

Calvino, Italo. 1985. Mr. Palomar. Tr. William Weaver; San Diego/New York/London: A Helen and Kurt Wolff Book/Harcourt Brace.

Creuzer, Friedrich. 1810. Symbolik und Mythologie der Alten Völker, Vol. 1. Leipzig: Karl Wilhelm Leske.

- 1811. Symbolik und Mythologie der Alten Völker, Vol. 2. Leipzig: Heyer \& Leske.

. 1812. Symbolik und Mythologie der Alten Völker, Vol. 4. Leipzig: Carl Wilhelm Leske.

- 1821. Symbolik und Mythologie der Alten Völker, Vol. 3. 2nd ed. 
Leipzig: Carl Wilhelm Leske.

Davy, John. 1821. An Account of the Interior of Ceylon, and of its Inhabitants. London: For Longman, Hurst, Rees, Orme, and Brown.

Dieterich, Albrecht. 1903. Eine Mithrasliturgie. Leipzig: B. G. Teubner. .1910. Eine Mithrasliturgie. 2nd ed. Leipzig and Berlin: B. G. Teubner.

Dionysius of Fourna. 1996. The 'Painter's Manual' of Dionysius of Fourna. Tr. Paul Hetherington. Torrance, CA: Oakwood Publications.

Ehrman, Bart D. \& Zlatko Pleše. 2011. The Apocryphal Gospels: Texts and Translations. New York: Oxford University Press.

Eissler, K. R. 1990. 'C.G. Jung: A Witness?' Unpublished. William McGuire, Papers Bx 86 Fd 11. Manuscript Department, Library of Congress, Washington, DC.

Fausbøll, Viggo. 1855. Dhammapadam: Ex Tribus Codicibus Hauniensibus. Copenhagen: C.A. Reitzels, London: Williams \& Norgate, Leipzig: Lorkius.

Feldman, Burton \& Robert D. Richardson. 1972. The Rise of Mythology: 1680-1860. Bloomington \& London: Indiana University Press.

Flanigan, Tom. 1996. 'Everyman or Saint? Doubting Joseph in the Corpus Christi Cycles' In Medieval \& Renaissance Drama in England 8:19-48.

Fourmont, Étienne. 1735. Réflexions critiques sur les histoires des anciens peuples. 2 vols.; Paris: Musier, Jombert, Briasson, Bullot.

Freud, Sigmund. \& Carl G. Jung. 1974. Freud-Jung Letters. Ed. W. McGuire. Tr. R. Manheim \& R. F. C. Hull. Princeton: Princeton University Press.

. 1974b. Sigmund Freud / Carl Jung: Briefwechsel. Ed. W. McGuire \& Wolfgang Sauerländer. Frankfurt Am Main: S. Fischer.

Gale, Colin \& Robert Howard. 2003. Presumed Curable: An Illustrated Casebook of Victorian Psychiatric Patients in Bethlem Hospital. Petersfield, UK \& Philadelphia, PA: Wrightson Biomedical.

Gatty, Chares T. 1882. Catalogue of the Mayer Museum Part II: Prehistoric Antiquities and Ethnography. London: Bradbury, Agnew.

Gibson, Gail McMurray. 1975. 'The Images of Doubt and Belief: Visual Symbolism in the Middle English Plays of Joseph's Troubles about 
Mary'. University of Virginia, $\mathrm{PhD}$ dissertation.

1989. The Theater of Devotion: East Anglian Drama and Society in the Late Middle Ages. Chicago and London: University of Chicago.

1990. 'The Thread of Life in the Hand of the Virgin.' In Julia Bolton Holloway, Constance S. Wright, and Joan Bechtold (eds.) Equally in God's Image: Women in the Middle Ages. New York: Peter Lang. 46-54.

Giovino, Mariana. 2007. The Assyrian Sacred Tree: A History of Interpretations. Orbis Biblicus et Orientalis 230. Fribourg: Academic Press/Göttingen: Vandenhoeck \& Ruprecht.

Guenther, Peter W. 1991. 'Introduction.' In Alois Wach Paris, Munich 1914-1919. New York: Brandt Dayton Gallery.

Haeckel, Ernest. 1874. Anthropogenie; oder, Entwickelungsgeschichte des Menschen. Keimes-und Stammesgeschichte (2nd ed.). Leipzig: Wilhelm Engelmann.

Healy, Nan Savage. 2017. Toni Wolff \& C.G. Jung: Collaboration. Los Angeles, CA: Tiberius Press.

Henderson, Jeffrey. 1991. The Maculate Muse: Obscene Language in Attic Comedy. 2nd ed. New York, Oxford: Oxford University Press.

Hesse, Herman. 1972. Stories of Five Decades. Ed. Theodore Ziolkowski; tr. Ralph Manheim \& Denver Lindley: New York: Farrar, Straus and Giroux.

—. 2001. 'Traumfährte' in Die Erzählungen 3 (1911-1954). Hermann Hesse Sämtliche Werke 8. Ed. Volker Michels. Berlin: Suhrkamp Verlag.

Higgins, Godfrey. 1836. Anacalypsis: An Attempt to Draw Aside the Veil of Saitic Isis; Or, An Inquiry into the Origin of Languages, Nations, and Religions. 2 vols. London: Longman, Rees, Orme, Brown, Green, and Longman.

Hislop, Alexander. 1871. Two Babylons: Or, the Papal Worship Proved to be the Worship of Nimrod and His Wife. S.W. Partridge.

Hogenson, George, B. 2004. 'Archetypes: Emergence and the Psyche's Deep Structure.' In Joseph Cambray, Joseph \& Linda Carter (eds). Analytical Psychology: Contemporary Perspectives in Jungian Analysis. Hove and New York: Brunner-Routledge:32-55. 
Huggins, Ronald V. 2019. 'On Śrīla Prabhupāda's insistence that "Christ" came from "Krishna." Journal of Hindu-Christian Studies 32:56-70.

Inman, Thomas. 1875 [1874]. Ancient Pagan and Modern Christian Symbolism Exposed and Explained. 2nd ed. New York: Trübner.

Jones, William. 1806 [1784]. 'On the Gods of Greece, Italy, and India.' Asiatick Researches 1:262.

Jung, C.G. 1911. 'Wandlungen und Symbole der Libido.' Jahrbuch für psychoanalytische und psychopathologische Forschungen 3(1):212. 1.Hälfte

1912. 'Wandlungen und Symbole der Libido'' Jahrbuch für psychoanalytische und psychopathologische Forschungen 4(1):162464.

1912a. Wandlungen und Symbole der Libido. Leipzig and Vienna: Franz Deuticke.

1916. Psychology of the Unconscious: A Study of the Transformations and Symbols of the Libido. Tr. Beatrice M. Hinkle. New York: Moffat, Yard.

- [1929]. 'The Significance of Constitution and Heredity in Psychology.' Collected Works of C.G. Jung. vol. 8, §§220-231.

- [1931]. 'The Structure of the Psyche.' Collected Works of C.G. Jung. vol. 8, §§283-342.

- [1934] 'Concept of the Collective Unconscious.' Collected Works of C.G. Jung. vol. 9.I $\S \S 87-110$.

. [1935]. 'The Tavistock Lectures.' Collected Works of C.G. Jung. vol. $18, \S \S 1-415$.

1938a. Wandlungen und Symbole der Libido. Leipzig and Vienna:

Franz Deuticke. It is into this edition that Jung entered corrections for Symbole der Wandlung (1952).

- 1938b. Psychology and Religion. New Haven, CT \& London: Yale University Press.

- 1952. Symbole der Wandlung. Zürich: Rascher.

- 1956. Symbols of Transformation. Tr. R.F.C. Hull. New York: Pantheon Books. Collected Works of C.G. Jung. vol. 5.

—. 1968. Psychology and Alchemy. 2nd ed.; Princeton, NJ: Princeton 
University Press. Collected Works. vol 12.

1972. Psychologie und Alchemie. 2nd ed. Walter-Verlag: Olten and Feiberg in Briesgau. Gesammelte Werke 12.

1973. Symbole der Wandlung. Walter-Verlag: Olten and Feiberg in Briesgau. Gesammelte Werke 5.

- 1991. Psychology of the Unconscious: A Study of the Transformations and Symbols of the Libido. Tr. Beatrice M. Hinkle. Ed. William McGuire. Princeton: Princeton University Press. Collected works of C.G. Jung Supp. vol. B.

- 2012. Introduction to Jungian Psychology: Notes of the Seminar on Analytical Psychology Given in 1925. Rev. ed. Ed. Sonu Shamdasani. Princeton \& Oxford: Princeton University Press.

Jung, Carl G. \& Freeman, John. 1959. 'The 'Face to Face' Interview with John Freeman, BBC television, Oct. 22, 1959.' In C.G. Jung Speaking: Interviews and Encounters. Eds. W. McGuire and R. F. C. Hull. Princeton: Princeton University Press, 1987.

Jung, Carl G. \& Jaffé, Aniela. 1965. Memories, Dreams, Reflections. Rev. ed. Tr. R. \& C. Winston. New York: Vintage Books.

_.2013. Erinnerungen, Träume, Gedanken. [Mannheim], Germany: Patmos.

Kaempfer, Engelbert. 1727. History of Japan. Tr. J. G. Scheuchzer; London: For the translator.

Kenny, Robert. 2015. 'Freud, Jung and Boas: The Psychoanalytic Engagement with Anthropology Revisited.' Notes and Records of the Royal Society of London 69:173-190.

Knight, Richard Payne. [1786]. A Discourse on the Worship of Priapus, and Its Connection with the Mystic Theology of the Ancients. London: Privately Printed, 1865.

Lachman, Gary. 2010. Jung the Mystic: The Esoteric Dimensions of Carl Jung's Life and Teachings: A New Biography. New York: Jeremy P. Tarcher/Penguin.

Landels, John G. 1999. Music in Ancient Greece and Rome. London \& New York: Routledge.

Lang, Andrew. 1897. Modern Mythology. London, New York, \& Bombay: Longmans, Green. 
Labriola, Albert C. \& John W. Smeltz. 2002. The Mirror of Salvation [Speculum Humanae Salvationis]: An Edition of British Library Blockbook G. 11784. Tr. with commentary; Pittsburg, PA: Duquesne University Press.

Lydgate, John. 1961. A Critical Edition of John Lydgate's Life of our Lady. Duquesne Studies Philological; Series 2; Joseph A. Lauritis, Ralph A. Klinefelter, and Vernon F. Gallagher (eds.); Pittsburgh, PA: Duquesne University Press/Leuven: Nauwelaerts.

Mead, G. R. S. 1907. A Mithraic Ritual. Echoes from the Gnosis 6. London and Benares: The Theosophical Publishing Society.

Meier, C.A. 1995 [1977]. Personality: The Individuation Process in Light of C. G. Jung 's Typology. Tr. David N. Roscoe: Einsiedeln, Switzerland. 78-79.

Miles, Laura Saetveit. 2014. 'The Origins and Development of the Virgin Mary's Book at the Annunciation' Speculum 89.3 (July):632-669.

Mitchell, T.C. 1988. The Bible in the British Museum: Interpreting the Evidence. London: British Museum Press.

Möller, Arnulf, Christian Scharfetter, \& Daniel Hell. 2002. 'Development and termination of the working relationship of C. G. Jung and Eugen Bleuler, 1900-1909.' History of Psychiatry 13 (52.4): 445-453.

Moor, Edward. 1810. Hindu Pantheon. London: J. Johnson.

Nes, Solrunn. 2000. The Mystical Language of Icons. Grand Rapids, MI: Eerdmans.

Noll, Richard. 1994. The Jung Cult: Origins of a Charismatic Movement. Princeton, NJ: Princeton University Press. 1997. The Aryan Christ: The Secret Life of Carl Jung. New York: Random House.

- [1992]. 'Jung the Leontocephalus.' In Paul Bishop (ed.) Jung in Contexts: A Reader. London and New York: Routledge:51-91, 1999.

Nork, Friedrich. 1843. Etymologisch-symbolisch-mythologisches RealWörterbuch zum Handgebräuche für Bibelforscher, Archäologen und bildende I. Stuttgart: J. F Cast.

Ouspensky, Léonide. 1982. 'The Annunciation' In Léonide Ouspensky and Vladimir Lossky The Meaning of Icons. Crestwood, NY: St. Vladimir's Seminary Press, 1982:171-173. 
Pape, Wilhelm. 1849. Griechisch-deutsches Handwörterbuch. 2 vols.; Braunschweig: Friedrich Vieweg \& Sohn. Jung owned the two-volume edition from the same year.

Pelikan. Jaroslav. 1996. Mary Through the Centuries: Her Place in the History of Culture. New Haven and London: Yale University Press.

Physiologus. 2009. Tr. Michael J. Curley; Chicago: University of Chicago Press.

[Rank, Otto]. 1910. Jahrbuch für psychoanalytische und psychopathologische Forschungen 2 (2):734-735.

Rawlinson, George. 1898. Memoir of Major-General Sir Henry Creswicke Rawlinson. Intro. Lord Roberts of Kandahar. New York \& Bombay: Longmans, Green.

Robb, David M. 1936. 'The Iconography of the Annunciation in the Fourteenth and Fifteenth Centuries.' The Art Bulletin 18 (4):485, nt. 21.

Rosenau, Helen. 1944. 'A Study of the Iconography of the Incarnation.' The Burlington Magazine for Connoisseurs 85.496 (July).

Rossner, Christiane. 2012. 'In Schwäbisch Hall sitzt Maria an einem Spinnrocken.' Monumente: Magazin für Denkmalkultur in Deutchland. (December): https://www.monumente-online.de/de/ ausgaben/2012/6/der-faden-des-lebens.php.

Schaff, Philip. [1931]. Creeds of Christendom. 3 vols.; 6th ed. Grand Rapids, MI: Baker Books (Orig. Harper and Row), 1993.

Schopenhauer, Arthur. 1969. The World as Will and Representation. Tr. E.F.J. Payne; 2 vols. New York: Dover.

1912-1913. Die Welt als Wille und Vorstellung. 2 vols. Ed. Ludwig Berndl; Munich: Georg Müller.

Schreber, Daniel Paul. 1903. Denkwürdigkeiten eines Nervenkranken. Leipzig: Oswald Mutze.

1988. Memoirs of my Nervous Illness. Tr. and ed. Ida Macalpine and Richard A. Hunter; new intro. Samuel M. Weber; Cambridge, MA \& London: Harvard University Press.

Scott, Alan. 1998. 'The Date of the Physiologus.' Vigiliae Christianae 52 (4) 430-441.

Shamdasani, Sonu. 2003. Jung and the Making of Modern Psychology: The Dream of a Science. Cambridge: Cambridge University Press. 
2012. C.G. Jung: A Biography in Books. New York \& London: W.W. Norton, in assoc. with The Martin Bodmer Foundation.

Smith, Dinitia 1995. 'Scholar Who Says Jung Lied Is at War with Descendants.' The New York Times (3 June):1,9.

Steffens, Dorothee \& Wharton, Barbara. 2001. 'Burghölzli Hospital Records of Sabina Spielrein.’ Journal of Analytical Psychology 46:1542.

Taylor, Catherine C. 2013. 'Painted Veneration: The Priscilla Catacomb Annunciation and the Protoevangelion of James as Precedents for Late Antique Annunciation Iconography.' In Allen Brent \& Markus Vinzent (eds.) Studia Patristica LIX.7: Early Christian Iconographies. Leuven, Paris, Walpole, MA: Peeters:21-37. Esp. 25 fig. 4,26, fig 6.

Traver, Hope. 1907. The Four Daughters of God: A Study of his Allegory with Especial Reference to those in Latin, French, and English. Philadelphia, PA: John C. Winston.

Vallancey, Charles. 1782. A Grammar of the Iberno-Celtic, or Irish Language (2nd ed.); Dublin: R. Marchbank, for G. Faulkner, T. Ewing, and R. Moncrieff.

1786. A Vindication of the Ancient History of Ireland. Dublin: for Luke White.

Vogel, J. Ph. [1936]. Buddhist Art in India, Ceylon and Java. Tr. A.J. Barnouw. New Delhi \& Madras: Asian Educational Services, 1998.

von Spiess, Karl. 1942. Marksteine der Volkskunst. 2 Tiel. Berlin: H. Stubenrauch.

Wachlmayr, Aloys. 1939. Das Christgeburtsbild der frühen Sakralkunst. Munich-Planneg: Otto Wilhelm Barth.

Walser, Hans H. (1973). 'Johann Jakob Honegger (1885-1911) Ein Beitrag zur Geschichte der Psychoanalyse.' Schweizer Archiv für Neurologie, Neurochirurgie und Psychiatrie 112, I:107-113.

. (1974). 'An Early Psychoanalytical Tragedy: J. J. Honegger and the Beginnings of Training Analysis'. Tr. A.K. Donoghue. Spring: An Annual of Archetypal and Jungian Thought:243-255.

Wyss, Robert L. 1960. 'Vier Hortus Conclusus-Darstellungen im Schweizerishen Landesmuseum. Zeitschrift für Schweizerische Archaeologie und Kunstgeschichte 20:113-124. 